University of Nebraska - Lincoln

DigitalCommons@University of Nebraska - Lincoln

Papers in the Earth and Atmospheric Sciences

Earth and Atmospheric Sciences, Department

January 2006

\title{
Diatom paleolimnological record of Holocene climatic and environmental change in the Altai Mountains, Siberia
}

\author{
Karlyn S. Westover \\ University of Nebraska-Lincoln \\ Sherilyn C. Fritz \\ University of Nebraska-Lincoln, sfritz2@unl.edu \\ Tatyana A. Blyakharchuk \\ Tomsk State University, Lenina 36, 634050, Tomsk, Russia \\ Herbert E. Wright \\ Limnological Research Center, University of Minnesota, 220 Pillsbury Hall, Minneapolis, MN
}

Follow this and additional works at: https://digitalcommons.unl.edu/geosciencefacpub

Part of the Earth Sciences Commons

Westover, Karlyn S.; Fritz, Sherilyn C.; Blyakharchuk, Tatyana A.; and Wright, Herbert E., "Diatom paleolimnological record of Holocene climatic and environmental change in the Altai Mountains, Siberia" (2006). Papers in the Earth and Atmospheric Sciences. 27.

https://digitalcommons.unl.edu/geosciencefacpub/27

This Article is brought to you for free and open access by the Earth and Atmospheric Sciences, Department of at DigitalCommons@University of Nebraska - Lincoln. It has been accepted for inclusion in Papers in the Earth and Atmospheric Sciences by an authorized administrator of DigitalCommons@University of Nebraska - Lincoln. 


\title{
Diatom paleolimnological record of Holocene climatic and environmental change in the Altai Mountains, Siberia
}

\author{
Karlyn S. Westover ${ }^{1, *}$, Sherilyn C. Fritz ${ }^{1,2}$, Tatyana A. Blyakharchuk ${ }^{3,4}$, and \\ Herbert E. Wright ${ }^{5}$ \\ ${ }^{1}$ Department of Geosciences, University of Nebraska-Lincoln, 214 Bessey Hall, Lincoln, NE 68588-0340, USA \\ ${ }^{2}$ Department of Biological Sciences, University of Nebraska-Lincoln, Lincoln, NE, 68588-0118, USA \\ ${ }^{3}$ Tomsk State University, Lenina 36, 634050, Tomsk, Russia \\ ${ }^{4}$ Institute for Monitoring of Climatic and Ecological Systems, 10/3, Akademichesky Ave., 634055, Tomsk, Russia \\ ${ }^{5}$ Limnological Research Center, University of Minnesota, 220 Pillsbury Hall, Minneapolis, MN 55455-0219, USA \\ * Corresponding author, email: coyote@unlserve.unl.edu
}

\begin{abstract}
The sedimentary diatom records of three shallow lakes in the Altai Mountains, southern Siberia, were examined to assess the nature and timing of Holocene environmental changes. Few paleoenvironmental records, especially reconstructions not based on pollen, have been reported from this region. The lakes differ in elevation, annual precipitation, and catchment vegetation. Diatom assemblages in all lakes were dominated for the entire period of record by small benthic species of Pseudostaurosira Williams \& Round, Staurosira Ehrenberg, and Staurosirella Williams \& Round. Planktonic taxa only occur in very low abundances $(<5 \%)$. The most diverse diatom flora was found in Dzhangyskol, which is situated at the lowest elevation within a forested catchment. A lack of detailed information on the ecological preferences of the dominant taxa and the complexity of environmental drivers make direct interpretation of the diatom record difficult. However, other proxies suggest that dramatic shifts in dominance between Staurosira elliptica and Staurosirella pinnata in Grusha Ozero reflect millennial-scale variability in climate. Together, chironomids and diatoms provide evidence of a cooling possibly correlative to the Younger Dryas Stade and subsequent early-Holocene warming consistent with pollen evidence of afforestation, which also is likely linked to increased humidity. By 6,000 cal year BP, the transition to a cooler, more continental climate had begun. The diatom record of Akkol shows significantly less variation in diatom community composition, but biogenic silica accumulation rates, a proxy for diatom productivity, appear to reflect climatic variability driven by insolation trends over the past 8,000 years. Long-term variability in Dzhangyskol is not clearly linked to climate.
\end{abstract}

Keywords: Altai Mountains, biogenic silica, diatoms, Holocene, insolation trends, paleoclimate, Siberia

\section{Introduction}

Mountain regions, as a consequence of steep gradients and climatic heterogeneity, are characterized by high ecosystem diversity. As the headwaters for many major rivers, mountains are also a central feature of the global hydrological cycle as well as a crucial source of environmental water for many human populations. Thus, understanding the history and impacts of climate change in mountain regions is es- 
pecially critical. Furthermore, many high-elevation sites have experienced recent warming exceeding hemispheric or global averages (Beniston et al. 1997) and may be particularly vulnerable to future climatic changes. Among the regions whose climatic history is poorly known are the southern mountain ranges of Siberia. The Altai Mountains stretch $1900 \mathrm{~km}$ along the shared borders of Russia (Siberia), Kazakhstan, China, and Mongolia. They are among the highest in Siberia and form the headwaters of the $\mathrm{Ob}$ and Yenisei rivers and of the interior Great Lakes Basin of northwest Mongolia.

The Altai Mountains serve as the locus for the annual development of the Siberian Anticyclone, a central feature of Northern Hemisphere circulation. Zonal flow into the continental interior is blocked during the winter by the Siberian Anticyclone, which is responsible for the calm, cold, and dry winters characteristic of continental Siberia and Mongolia. Periodic additions of arctic anticyclones during winter result in spatial and temporal variability in the strength of the High (Lydolph 1977). Intense heating of the land surface during the summer results in diffuse low pressures over much of the continent, favorable for the penetration of maritime air masses into the interior. Consequently, in the summer, the continental interior experiences a pronounced precipitation maximum. The Altai are characterized by short, cool summers, with a growing season ranging from 160 days in the foothills to 60 days at high elevations (Borisov 1965).

In this paper, we reconstruct the diatom stratigraphies for three lakes in the Altai Mountains. We compare the diatom records with pollen and chironomid data from the same lakes to infer the paleoenvironmental history of this poorly documented region.

\section{Paleoclimate setting}

Variations in magnitude and latitudinal distribution of insolation are invoked as the major forcing mechanism for millennial-scale climatic variability during the Holocene in Eurasia (Harrison et al. 1996). In the Northern Hemisphere, between 12,000 and 6,000 year $\mathrm{BP}$, variation in the latitudinal distribution of insolation anomalies reduced the latitudinal temperature gradient (Yu and Harrison 1995). Based upon at- mospheric circulation patterns of the modern climate system, it is hypothesized that this reduced gradient shifted the latitude of westerly air mass penetration northward. An additional consequence of the insolation anomalies is the enhancement of land-sea temperature contrasts. This is likely to have increased the strength of both the winter Icelandic low and the summer Azores high, resulting in increased penetration of maritime air masses into the continental interior of Eurasia during both winter and summer (Harrison et al. 1992). Milder conditions in the interior also may have resulted from a decrease in anticylonic activity in the Arctic, which sustains the Siberian High during winter today.

Pollen records of late-glacial and Holocene climate generally follow the patterns predicted by variation in insolation. The late-glacial climate of the interior of northern Eurasia (Figure 1a) is inferred to have been cold and dry (Khotinskiy 1984), with tundra-steppe vegetation in the present-day forest zone of west Siberia (Blyakharchuk and Sulerzhitsky 1999). By $14,000{ }^{14} \mathrm{C}$ year BP $(15,000 \mathrm{cal}$ year BP $)$, periglacial landscapes of the Ulagan Plateau in the central Altai were replaced by pioneer meadowshrub-grass vegetation followed by a treeless dry steppe (Blyakharchuk et al. 2004).

Early-Holocene warmth is evidenced by widespread melting of permafrost and the northward expansion of the arctic treeline across northern Eurasia (Figure 1b). Macrofossil-and pollen-based reconstructions indicate the advance of Betula, Larix, Picea, and Pinus beyond their modern limits between 9,000 and $8,000{ }^{14} \mathrm{C}$ year BP $(10,200$ and 8,900 cal year BP) (Peteet et al. 1998; MacDonald et al. 2000; Davydova et al. 2001; Pisaric et al. 2001; Andreev et al. 2002; Väliranta et al. 2003). Early-Holocene warming is also indicated by an upslope movement of alpine treeline in the northern Urals (Kultti et al. 2003), by paleolimnological records from the northwest Siberian Arctic (Laing et al. 1999; Porinchu and Cwynar 2002), and by widespread initiation of peatland development in the West Siberian Lowland between 9,500 and 7,000 ${ }^{14} \mathrm{C}$ year BP $(11,000$ and 8,000 cal year BP) (Kremenetski et al. 2003). In the southeastern Altai, Ponomareva et al. (1991) and Butvilovsky (1993) suggest, based on macrofossil evidence, that altitudinal vegetation belts were 400-500 m higher. In the central Altai, the develop- 
(a) Late Glacial: 12,000 to 11,000 "c $\mathrm{yr}$ BP (14,000 to 13,000 cal yr BP)

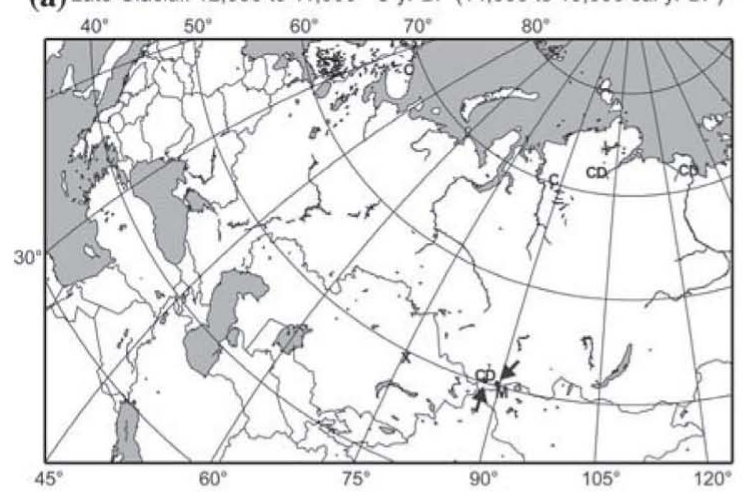

(c) Mid-Holocene: 7000 to $5500{ }^{14} \mathrm{C}$ yr BP (7800 to 6300 cal yr BP)

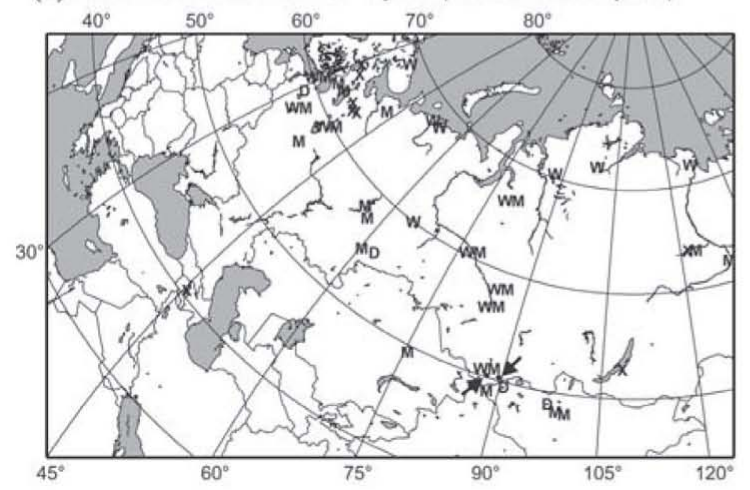

(b) Early Holocene: 9500 to $8500{ }^{14} \mathrm{C}$ yr BP (10,800 to 9500 cal yr BP)

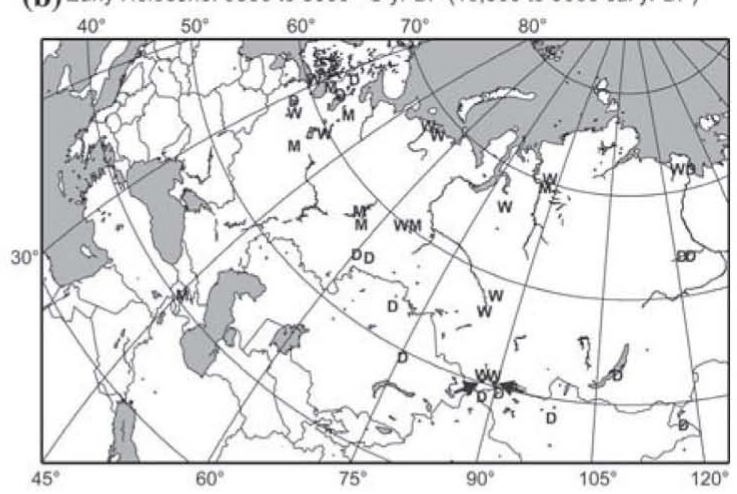

(d) Late Holocene: 3000 to 2000 '"C yr BP (3200 to 2000 cal yr BP)

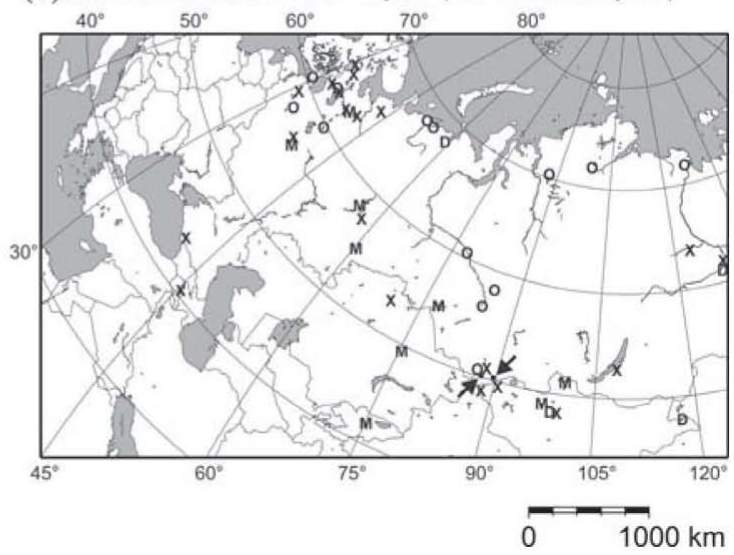

Figure 1. Summary diagram of published paleoclimate data (Ponomareva et al. 1991; Butvilovsky 1993; Harrison et al. 1996; Peteet et al. 1998; Blykharchuk and Sulerzhitsky 1999; Laing et al. 1999; MacDonald et al. 2000; Tarasov et al. 2000; Wolfe et al. 2000; Davydova et al. 2001; Pisaric et al. 2001; Andreev et al. 2002; Glebov et al. 2002; Blyakharchuk 2003; Fowell et al. 2003; Väliranta et al. 2003; Kultti et al. 2003; Blyakharchuk et al. 2004). Inferred climates for the (a) Late-glacial, (b) early-Holocene, (c) mid-Holocene, and (d) late-Holocene, as interpreted by the authors, are presented relative to modern climate. Letters denote direction of climate change: $\mathrm{C}=$ cooler, $\mathrm{W}$ = warmer, $\mathrm{O}=$ no temperature difference, $\mathrm{M}$ = higher effective moisture, $\mathrm{D}=$ lower effective moisture, and $\mathrm{X}=$ no moisture difference. Locations of this study's paleolimnological sites are denoted by arrows.

ment of closed forests featuring mesophilous species of Picea and Abies at elevations below 2,000 m (Blyakharchuk et al. 2004) imply a warmer and more humid climate. In contrast, paleolimnological records from sites in European Russia, Mongolia, and northeast Siberia indicate an early-Holocene climate that was drier than present, driven by greater-than-present summer insolation (Harrison et al. 1996; Wolfe et al. 2000; Davydova et al. 2001). The development of birch forest-steppe in southwest Siberia also indicates a warm and dry climate (Blyakharchuk 2003).

Climate reconstructions based on lake level (Harrison et al. 1996) and pollen (Tarasov et al. 1999) in- dicate enhanced moisture in most of northern Eurasia during the mid-Holocene (Figure 1c). The period from 7,000 to $5,000{ }^{14} \mathrm{C}$ year $\mathrm{BP}(7,800-5,700 \mathrm{cal}$ year BP) is inferred to have been the warmest and most humid of the Holocene in Arctic Russia (Peteet et al. 1998; Wolfe et al. 2000; Davydova et al. 2001; Andreev et al. 2002) and western Siberia (Blyakharchuk and Sulerzhitsky 1999; Glebov et al. 2002; Blyakharchuk 2003). In west and southwest Siberia, dense forests replaced steppe communities during this period (Blyakharchuk and Sulerzhitsky 1999; Blyakharchuk 2003). In northwestern Mongolia, early-Holocene steppe was replaced by boreal coni- 
fer steppe-forest by the mid-Holocene (Tarasov et al. 2000). Lakes in western Siberia, northwestern Mongolia, and northeastern Siberia suggest a more humid climate between 7,500 and 6,000 ${ }^{14} \mathrm{C}$ year $\mathrm{BP}(8,300$ and 6,800 cal year BP) (Harrison et al. 1996; Tarasov et al. 2000). The only region where mid-Holocene climate is inferred to be relatively arid is in northern and central Mongolia, including Lake Telmen (Tarasov et al. 1999; Peck et al. 2002; Fowell et al. 2003).

Late-Holocene cooling led to the retreat of the arctic treeline to its modern position between 4,000 and 3,,000 ${ }^{14} \mathrm{C}$ year BP (4500 and ,3200 cal year BP) (MacDonald et al. 2000; Pisaric et al. 2001; Andreev et al. 2002; Väliranta et al. 2003) and, in western Siberia, to permafrost development and, in the south, renewed peat accumulation (Blyakharchuk and Sulerzhitsky 1999; Kremenetski et al. 2003) (Figure 1d). In the central Altai, a shift to a cooler and more continental climate is inferred from the near disappearance by $5,300{ }^{14} \mathrm{C}$ year BP $(6,000 \mathrm{cal}$ year BP) of Abies and Picea from the Ulagan Plateau (Blyakharchuk et al. 2004). In Mongolia, most lake-level records indicate decreased effective moisture after $6,000{ }^{14} \mathrm{C}$ year BP (6,800 cal year BP) (Harrison et al. 1996). However, at Lake Telmen, the period between 4,000 and $1,600{ }^{14} \mathrm{C}$ year BP $(4,500$ and 1,600 cal year BP) was the most humid of the Holocene, probably as a result of cooling (Peck et al. 2002; Fowell et al. 2003). A late-Holocene highstand is also recorded at Lake Hövsgöl in northern Mongolia (Fowell et al. 2003).

\section{Study area}

The rugged topography and continental setting of the Altai Mountains give rise to significant spatial variability in climate and a diversity of biomes. The most complete sequence of vegetation zones in Western Siberia is found in the Altai (Koropachinsky 1996). Enhanced moisture associated with orographic lifting promotes expansion of forest, which includes humid species Abies sibirica and Picea obovata, in the western and northern ranges. As mean annual precipitation decreases to the south and east, Pinus sibirica and Larix sibirica come to dominate. In these drier regions, the forest belt may disappear altogether, particularly on south-facing slopes (Malyshev and Nimis 1997). At higher elevations, a decline in alpine meadow vegeta- tion and development of high-mountain tundra-steppe is associated with decreasing precipitation from west to east. Intermontane basins of the Russian Altai are characterized by steppe vegetation.

The three study lakes (Figure 2) are situated in landscapes that differ in precipitation, elevation, and vegetation. Dzhangyskol $\left(50.18^{\circ} \mathrm{N}, 87.73^{\circ} \mathrm{E}\right.$; $1,830 \mathrm{~m}$ a.s.l.), a 60 -ha lake located in Kurai basin, is situated adjacent to a pingo field and frozen fen. The modern lake is a remnant of a once larger ice-dammed lake that was partially drained during the early-Holocene (Blyakharchuk and Wright, unpublished data). The Kurkurek River, which does not flow into Dzhangyskol at present, flows along the southern boundary of the pingo field. Locally bordering Dzhangyskol is meadow-steppe vegetation, with $P$. sibirica and $L$. sibirica on surrounding slopes. Approximately $135 \mathrm{~km}$ to the east, Grusha Ozero (50.38 $\mathrm{N}, 89.45^{\circ} \mathrm{E} ; 2,413 \mathrm{~m}$ a.s.l.) and Akkol (50.25 $\mathrm{N}, 89.62^{\circ} \mathrm{E}$; 2,204 m a.s.l.) are situated in the high-elevation (2,000-2,500 m) Karaginskaya basin of southwestern Tuva, part of the Mongolian Interior Lakes drainage basin. Grusha Ozero is a 130-ha headwater lake situated within a belt of alpine tundra. Akkol, 350 ha and second in the lake chain, is surrounded by steppe vegetation. Table 1 provides a summary of climatic data from the three meteorological stations nearest to the study area. All three lakes are shallow $(<4 \mathrm{~m})$. Grusha Ozero and Akkol are circumneutral, oligomesotrophic lakes (Table 2). Limnological data are not available for Dzhangyskol.

\section{Methods}

Field

Sediment was recovered from the middle of the lakes with a square-rod piston corer (Wright Jr. 1991) in the summers of 1998 (Dzhangyskol) and 2000 (Grusha Ozero and Akkol). Unconsolidated surface sediments were obtained with a clear plastic tube fitted with a piston and sampled vertically in the field. At Dzhangyskol, $376 \mathrm{~cm}$ of sediment $(64 \mathrm{~cm}$ gray silt overlain by $312 \mathrm{~cm}$ of alternating light calcareous and dark gyttja) were collected from the middle of the lake at a water depth of $1.2 \mathrm{~m}$. A 48-cm segment of sediment from 212 to $260 \mathrm{~cm}$ was not recov- 


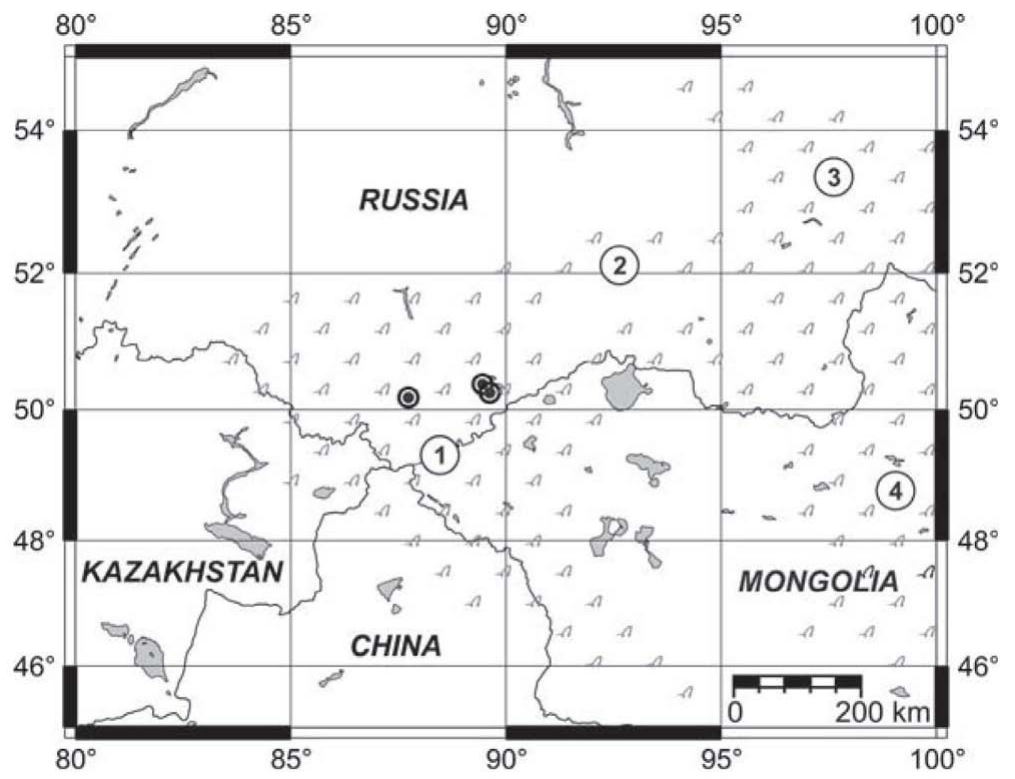

Figure 2. Map of study region, showing location of investigated lakes. Mountain ranges depicted are (1) Altai, (2) Western Sayan, (3) Eastern Sayan, and (4) Khangai.

Table 1. Climate data from Altai meteorological stations.

\begin{tabular}{|c|c|c|c|c|c|}
\hline Meteorological station & Elev. (m) & $\begin{array}{l}\text { Mean annual } \\
\text { prec. (mm) }\end{array}$ & $\begin{array}{l}\text { Mean January } \\
\text { temp (C) }\end{array}$ & $\begin{array}{l}\text { Mean July } \\
\text { temp (C) }\end{array}$ & $\begin{array}{l}\text { Days with mean } \\
\mathrm{T}>10 \mathrm{C}\end{array}$ \\
\hline Chemal $\left(51.43^{\circ} \mathrm{N}, 86.00^{\circ} \mathrm{E}\right)$ & 420 & 529 & -12.4 & 18.1 & 131 \\
\hline Ust' Ulagan $\left(50.70^{\circ} \mathrm{N}, 87.98^{\circ} \mathrm{E}\right)$ & 1260 & 291 & na & 13.8 & 86 \\
\hline Kosh-Agach $\left(50.02^{\circ} \mathrm{N}, 88.68^{\circ} \mathrm{E}\right)$ & 1758 & 117 & na & 13.8 & 85 \\
\hline
\end{tabular}

Data compiled from Malyshev and Nimis (1997), WWF Climate Program (2001), and Groisman (1998).

ered. At Grusha Ozero, $249 \mathrm{~cm}$ of sediment were obtained from a water depth of $3.55 \mathrm{~m}$. The sediment was composed of $13 \mathrm{~cm}$ of gray silt overlain by 236 $\mathrm{cm}$ of light and dark brown gyttja. At Akkol, $470 \mathrm{~cm}$ of sediment were recovered from a water depth of $2.8 \mathrm{~m}$. The sediment consisted of $68 \mathrm{~cm}$ of silty clay overlain by $402 \mathrm{~cm}$ of olive-gray gyttja.

Table 2. Measured nutrients, total organic carbon (TOC), and $\mathrm{pH}$ from Grusha Ozero and Akkol.

\begin{tabular}{lll}
\hline & Grusha Ozero & Akkol \\
\hline $\mathrm{TN}(\mathrm{mg} / \mathrm{l})$ & 9.1 & 9.1 \\
$\mathrm{TP}(\mu \mathrm{g} / \mathrm{l})$ & 13.7 & 12.7 \\
$\mathrm{H}_{4} \mathrm{SiO}_{4}(\mathrm{mg} / \mathrm{l})$ & 2.9 & 3.3 \\
$\mathrm{TOC}(\mathrm{mg} / \mathrm{l})$ & 0.3 & 0.4 \\
$\mathrm{pH}$ & 6.5 & 7.3 \\
\hline
\end{tabular}

Water chemistry data is not available for Dzhangyskol.

\section{Laboratory}

Sediments were sampled at semi-regular intervals for loss-on-ignition, pollen, chironomids, biogenic silica and diatom analyses. Surface cores were sampled in 1 -cm increments at $5 \mathrm{~cm}$ intervals, with the exception of the Dzhangyskol surface core, which was sampled in contiguous $1-\mathrm{cm}$ sections for the first $20 \mathrm{~cm}$ and contiguous 2-cm sections for the bottom $40 \mathrm{~cm}$. The sub-surface piston cores were sampled in 1-cm increments at varying intervals based on apparent differences in sedimentation rate both between and within cores. The sampling resolution of diatoms and biogenic silica, reported in this manuscript, was dictated by sample availability.

Terrestrial macrofossils, charcoal, and bulk sediment also were collected for ${ }^{14} \mathrm{C}$ dating by accelera- 
tor mass spectrometry (AMS). Calibrated ages were determined by CALIB 4.4 (Stuiver and Reimer 1993; Stuiver et al. 1998a, b) based on a $2 \sigma$ error. Results are reported in Table 3.

Lake sediments were analyzed following standard procedures for loss-on-ignition at 550 and $950{ }^{\circ} \mathrm{C}$ as an estimation of organic matter and carbonate content, respectively (Heiri et al. 2001).

\section{Biogenic silica}

Biogenic silica (BSi) determinations were made via wet-alkaline extraction (DeMaster 1979). Approximately $30 \mathrm{mg}$ of freeze-dried sediment, homogenized by mortar and pestle, were digested with a weak base $\left(1 \% \mathrm{Na}_{2} \mathrm{CO}_{3}\right)$ at $85{ }^{\circ} \mathrm{C}$ in a water-bath shaker. Aliquots were withdrawn every hour for $5 \mathrm{~h}$. Dissolved silica concentrations of the aliquots were determined spectrophotometrically with a Cary Bio 100 UV-visible Spectrophotometer, based on the formation of a blue silicomolybdate complex. Because some leaching of mineral silicates commonly occurs, the intercept of a least-squares linear regression of dissolved silica concentration at 3, 4, and $5 \mathrm{~h}$ was used to estimate BSi concentration (Conley 1998; Conley and Schelske 2001). Where there was no increase in dissolved silica concentration with time, the mean of the 3, 4, and 5 h extractions was used to estimate biogenic silica concentration. As a check on both internal consistency and consistency with other laboratories, an interlaboratory comparison sample was included with each batch of samples. Measured BSi concentrations for this sample were within one standard deviation of that reported by Conley (1998).

BSi is a proxy for diatom abundance and may reflect diatom productivity (Conley and Shelske 2001). BSi concentrations, however, may not accurately reflect paleoproductivity if sedimentation rates are variable over the period of record. Therefore, mass accumulation rates of BSi were calculated for Akkol, which has a well constrained chronology, based on sediment dry density, estimates of linear sedimentation rate, and BSi concentration.

\section{Diatoms}

Following treatment in 10\% hydrochloric acid and $35 \%$ hydrogen peroxide to remove carbonates and organic matter, respectively, diatom samples were mounted on glass slides with Naphrax ${ }^{\circledR}$ and examined at $1000 \times$ under oil immersion with a Zeiss Axioskop 2 light microscope. Diatom assemblages were characterized by counts of 300-500 valves, with a single exception where only 105 intact valves were encountered in 10 transects across the slide. Scanning Electron Microscopy (JEOL JSM-T330) was also used to resolve uncertainties in species identifications. Taxonomic identifications were made with reference to multiple taxonomic references, including Krammer and Lange-Bertalot (1986-1991), Camburn and Charles (2000), Lange-Bertalot and Metzeltin (1996), Fallu et al. (2000), Williams and Round (1987), and Haworth (1974).

Two standard alpha diversity indices, Shannon diversity $\left(H^{\prime}\right)$ and Evenness $(E)$ were employed to explore how diatom community structure has changed throughout the lakes' histories.

$$
\begin{aligned}
& H^{\prime}=-\sum_{i=1}^{S} p_{i} \ln p_{i} \\
& E=\frac{H^{\prime}}{\ln S}
\end{aligned}
$$

$S=$ total number of species, $p_{i}=$ proportion of the $i$ th species.

Specimens that could not be identified to at least the species level (usually for reasons of preservation) were excluded in the determination of sample diversity. Varieties were considered as separate and distinct taxa in diversity analysis.

\section{Multivariate numerical analyses}

The rarest taxa, as well as those that could not be identified to species level, were excluded from numerical analysis. Only species or varieties occurring in relative abundances of at least $2 \%$ in one sample were retained. A total of 49 taxa were retained in the Dzhangyskol dataset, 26 in the Grusha Ozero dataset, and 14 in the Akkol dataset. These retained taxa accounted for 76-99\% (median 91\%) of the Dzhangyskol assemblages, 74-99\% (median 92\%) of the Grusha Ozero assemblages, and 72-100\% (median 96\%) of the Akkol assemblages. 


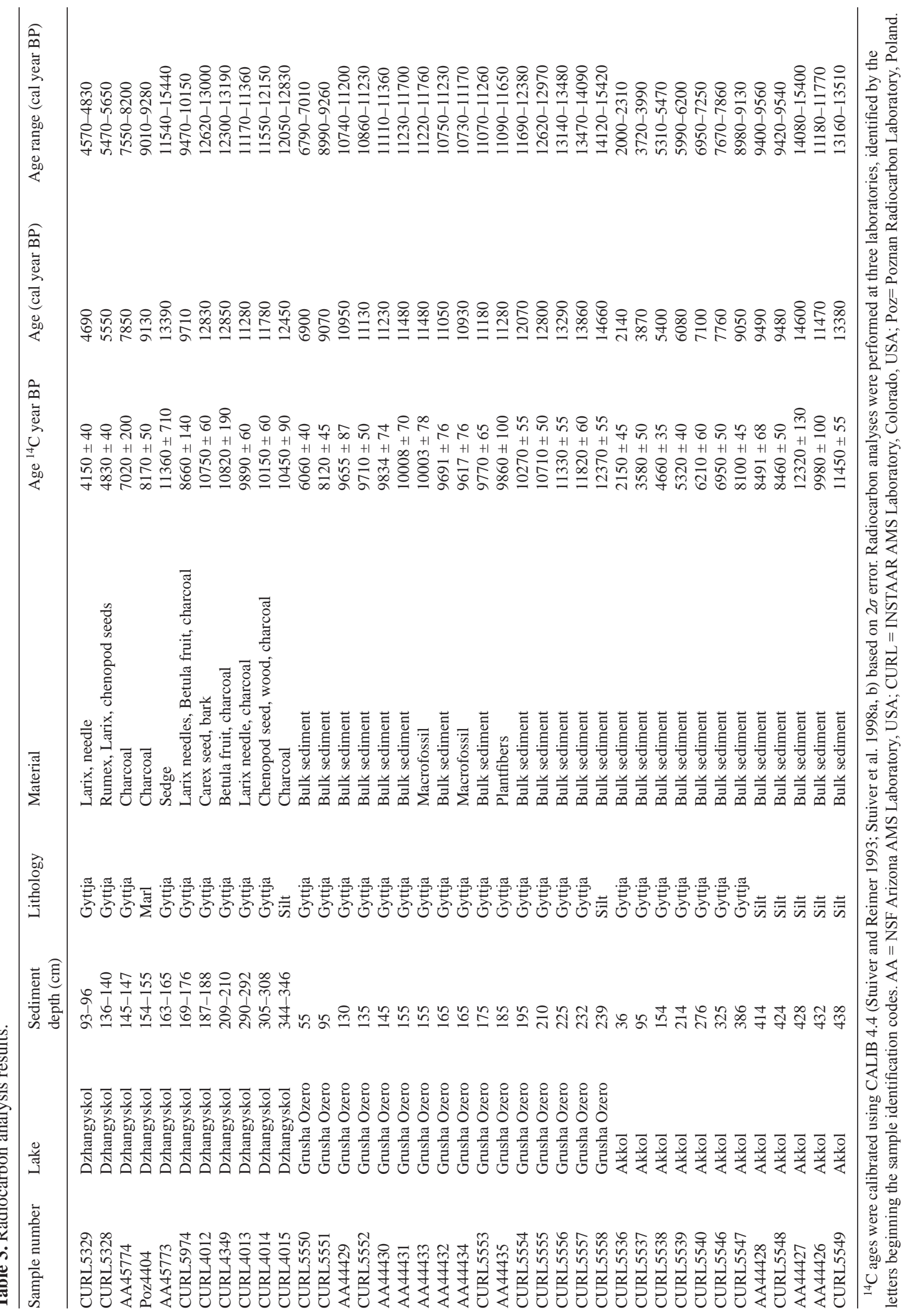


Diatom assemblage zones were defined by stratigraphically constrained cluster analysis by the incremental sum of squares (CONISS) algorithm using psimpoll 4.10 (Bennett 2002). Prior to analysis, species relative abundance data were square-root transformed, and the resultant dissimilarity coefficient is chord distance. The effect of the transformation is to maximize the signal-to-noise ratio in the data by upweighting subdominant taxa and is considered most appropriate for species abundance data (Overpeck et al. 1985). The number of statistically significant zones was determined by the broken-stick model (Bennett 1996).

Ordination analysis was employed to identify theoretical gradients that best explain observed variability in the diatom species data. Detrended Correspondence Analysis (DCA) with down-weighting of rare taxa, detrending by segments, and linear rescaling was performed on relative abundance data using CANOCO 4.5 (ter Braak and Šmilauer 1998). DCA revealed gradient lengths of 2.55, 1.94, and 1.06 standard deviation (SD) units for Dzhangyskol, Grusha Ozero, and Akkol, respectively. Because none of these gradients exceeded 3 SD units, Principal Components Analysis (PCA) was selected as the most appropriate ordination method (Lepš and Šmilauer 2003). PCA was performed on the covariance matrix of the diatom relative abundance data with no other transformation.

\section{Results}

\section{Dzhangyskol}

\section{Chronology}

The eleven radiocarbon dates obtained from the Dzhangyskol core (Table 3) reflect the lake's complex depositional history, a full discussion of which is in preparation by Blyakharchuk and Wright. The three oldest dates $(163-210 \mathrm{~cm})$ are interpreted to be reworked late-glacial material deposited during a low stand, following failure of the ice dam that created the lake. An unconformity is inferred from the lack of material between approximately 5,500 and 7,500 cal year BP in age. Age of sediments is estimated by linear interpolation for intervals preceding and following the depositional hiatus (Figure 3a).

\section{Loss-on-ignition}

As estimated by loss-on-ignition at $550{ }^{\circ} \mathrm{C}\left(\mathrm{LOI}_{550}\right)$, organic-matter content is very low from the base of the core to $308 \mathrm{~cm}(\sim 11,800$ cal year BP) (Figure $4 \mathrm{a})$, corresponding to the basal silt. Subsequently organic-matter content increases to nearly $50 \%$ at 270 cm ( 11,000 cal year BP). There is an abrupt decrease in organic-matter content and an increase in carbonate content, inferred from loss-on-ignition at $950{ }^{\circ} \mathrm{C}\left(\mathrm{LOI}_{950}\right)$, at $269 \mathrm{~cm}$. This change in sediment character is reflected in a transition from a dark gyttja to a gray calcareous gyttja. Between 269 and $96 \mathrm{~cm}$ ( 11,000-4,700 cal year BP), organic-matter content is variable, ranging from 8 to $41 \%$. Fluctuations in the percent $\mathrm{LOI}_{950}$ between 4 and 32\% also occur in this interval, indicating the presence of carbonates in significant amounts. Above and below this interval, the percent $\mathrm{LOI}_{950}$ never exceeds $4 \%$, and carbonate content is insignificant. Above $96 \mathrm{~cm}$, organicmatter content declines until $64 \mathrm{~cm}(\sim 3,200$ cal year BP). From $64 \mathrm{~cm}$, organic-matter content steadily increases to $63 \%$ at $5 \mathrm{~cm}(\sim 200 \mathrm{cal}$ year BP).

\section{Biogenic silica}

For much of the sedimentary record, BSi concentrations are low (Figure 4a). Below $96 \mathrm{~cm}(\sim 4,700$ cal year BP), BSi never exceeds $50 \mathrm{mg} \mathrm{g}^{-1}$. BSi increases to $100 \mathrm{mg} \mathrm{g}^{-1}$ by $80 \mathrm{~cm}(\sim 4,000$ cal year BP). Between 48 and $59 \mathrm{~cm} \mathrm{(} \mathrm{2,400} \mathrm{and} \mathrm{2,900} \mathrm{cal} \mathrm{year}$ $\mathrm{BP}), \mathrm{BSi}$ concentrations decline before increasing once more to levels near $100 \mathrm{mg} \mathrm{g}^{-1}$. Maximum BSi concentrations of $\sim 140 \mathrm{mg} \mathrm{g}^{-1}$ occur in two samples from 17 to $19 \mathrm{~cm}$ ( 800-900 cal year BP).

\section{Diatoms (Figure 5)}

DZH-1 (48-308 cm, 2,400-11,800 cal year BP). A gap in sediment recovery of $48 \mathrm{~cm}$, which represents $\sim 700$ years of the early-Holocene, divides this zone into two subzones, 261-308 cm and 48-210 cm. Diatoms first appear in abundance at $308 \mathrm{~cm}$. Below this depth, diatom valves are extremely rare and usually broken. This zone is characterized by large inter-sample variability. At $308 \mathrm{~cm}$, the assemblage is dominated by the benthic colonial species Pseudostaurosira binodis (Ehrenberg) Edlund, which is found occasionally in much lower abundances in the rest of the core. The diatom assemblage is subsequently characterized by a short-lived but marked 
(a) Dzhangyskol

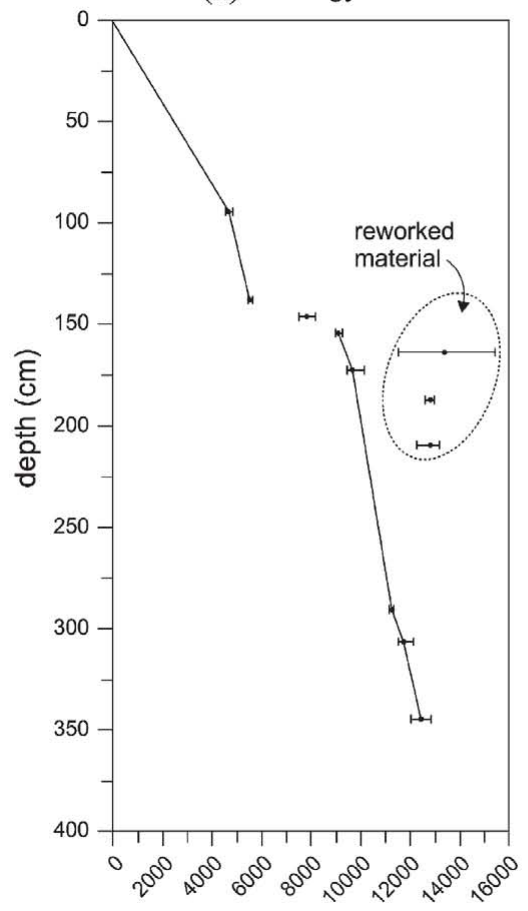

Cal age (years BP) (b) Grusha Ozero

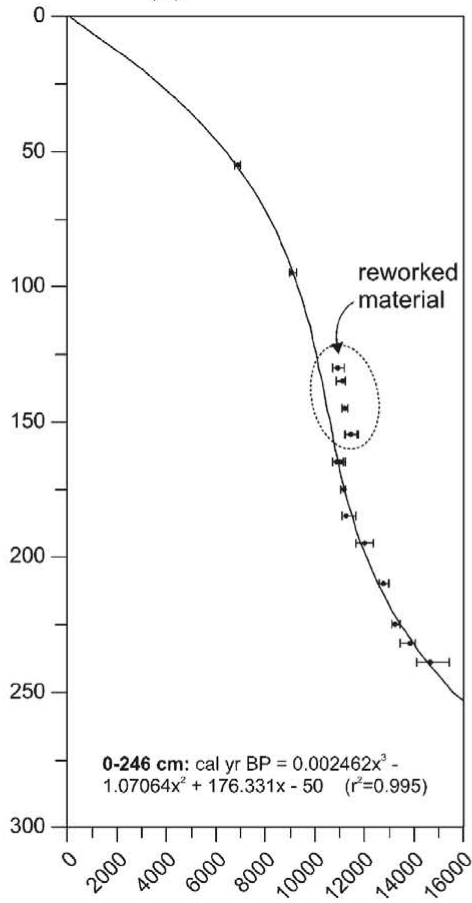

Cal age (years BP) (c) Akkol

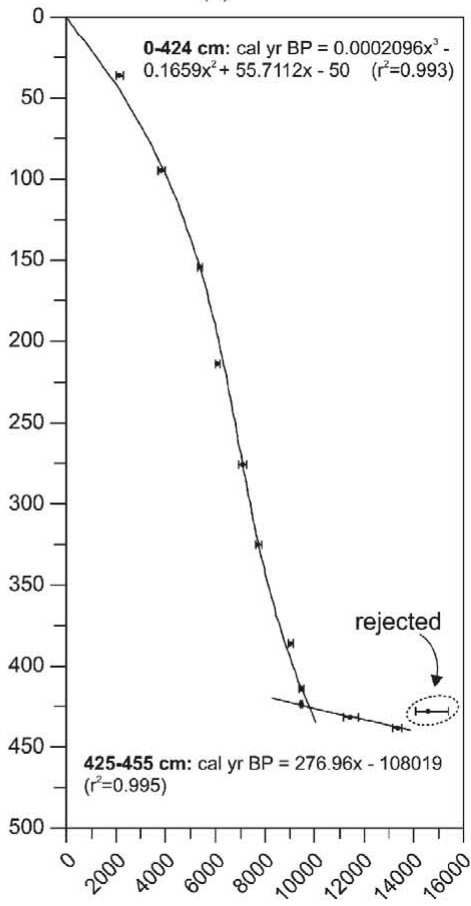

Cal age (years BP)

Figure 3. Age-depth models of the study lakes. The age of Dzhangyskol sediment, above and below an inferred hiatus at approximately $140 \mathrm{~cm}$, is estimated by linear interpolation between calibrated radiocarbon samples. Three stratigraphically inverted dates in Dzhangyskol are interpreted as late-glacial material redeposited following the failure of an ice dam and partial draining of the lake. Fitted polynomial age models are given for Grusha Ozero and Akkol. Five Grusha Ozero dates, between 130 and 155 cm, interpreted as redeposited sediment, are excluded from that model.
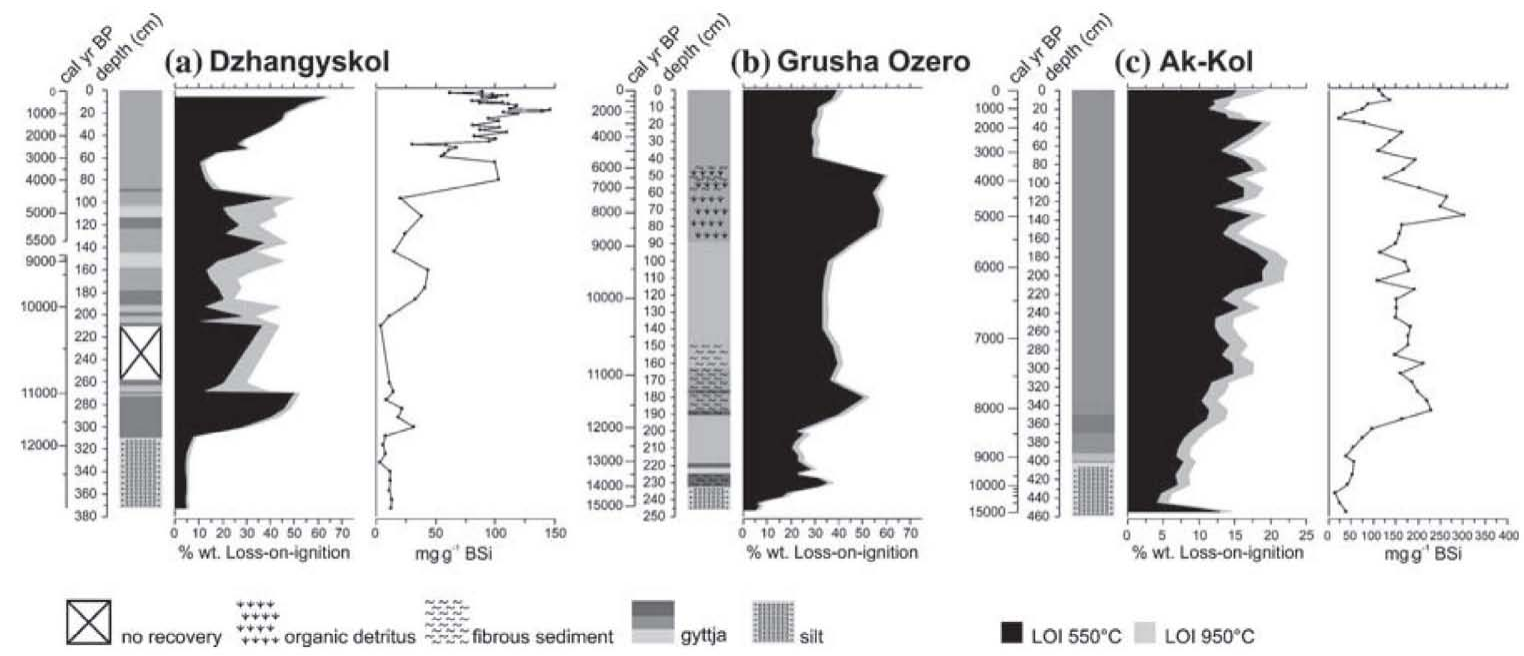

Figure 4. Lithology and stratigraphic profiles of loss-on-ignition and biogenic silica for (a) Dzhangyskol, (b) Grusha Ozero (no BSi), and (c) Akkol, plotted as a function of depth. Non-linear age scales are also provided to the left of each profile.

increase in diversity at $300 \mathrm{~cm}(\sim 11,600 \mathrm{cal}$ year $\mathrm{BP})$. The most abundant taxa, which range in relative abundance from 11 to $7 \%$, respectively, are Ach- nanthidium minutissimum (Kützing) Czarnecki (all varieties), Cocconeis placentula v. lineata (Ehrenberg) Van Heurck, Cymbella leptoceros (Ehrenberg) 


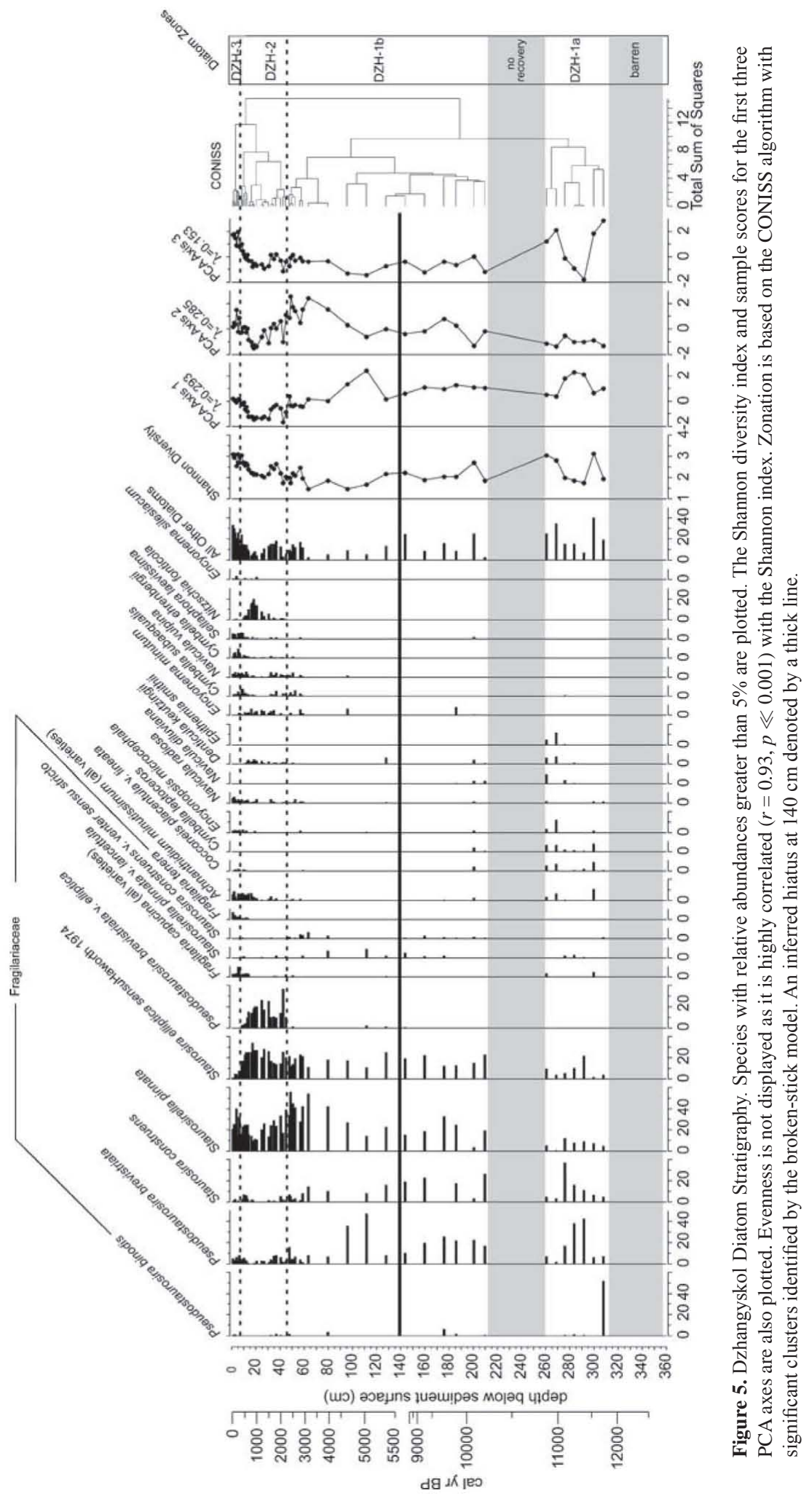


Kützing, and Staurosirella pinnata (Ehrenberg) Williams \& Round. Thereafter, assemblages are characterized by increased abundances of benthic colonial Fragilariaceae taxa including Pseudostaurosira brevistriata (Grunow in Van Heurck) Williams \& Round, Staurosira construens Ehrenberg, and Staurosira elliptica (Schumann) Williams \& Round sensu Haworth 1974. At $269 \mathrm{~cm}(\sim 11,000$ cal year BP), the dominant Fragilariaceae taxa decline and diversity increases once again, with Navicula diluviana Krasske, Epithemia smithii Carruthers, Encyonopsis microcephala (Grunow) Krammer, and Denticula keutzingii Grunow occurring at their maximum abundances. Taxa important during the earlier rise in diversity also increase in abundance once again. Subzone DZH-1b is defined by the return to dominance of Fragilariaceae taxa, including $P$. brevistriata, S. pinnata, S. elliptica, and S. construens. Staurosirella pinnata increases in abundance at the top of this zone, while abundances of P. brevistriata and $S$. construens decline. The dominance of these Fragilariaceae taxa produces the lowest average value in the diversity indices of the entire record. At $60 \mathrm{~cm}$ ( 3,000 cal year BP), diversity increases, with occurrences of Cymbella subaequlis Grunow, Encyonema minutum (Hilse ex Rabenhorst) Mann, Navicula radiosa Kützing, and Navicula vulpina Kützing.

DZH-2 (8-46 cm, ca. 350-2300 cal year BP). This zone is characterized by the first significant occurrence of $P$. brevistriata v. elliptica (Héribaud) Williams \& Round, with S. elliptica as co-dominant. Staurosirella pinnata declines during this period. The top of this zone (8-14 cm, ca. 350-650 cal year $\mathrm{BP}$ ) is transitional to zone DZH-3, featuring decreasing abundance of $P$. brevistriata v. elliptica and $S$. elliptica, increasing abundance of $S$. pinnata, and a trend of increasing diversity. This zone is also characterized by the rise and subsequent decline in abundance of Nitzschia fonticola Grunow. Additional taxa emerging in increased relative abundance in this zone include Fragilaria capucina Desmazières (all varieties), A. minutissimum (all varieties), D. keutzingii, and Sellaphora laevissima (Kützing) Mann.

DZH-3 (1-7 cm, 0-ca. 300 calendar years BP). This zone is characterized by diversity second only to that of the earliest assemblages. Of the small benthic colonial taxa, only $S$. pinnata is present in significant abundance. Fragilaria tenera (W. Smith) Lange-Bertalot and Cymbella ehrenbergii Kützing reach their maximum abundances in this zone.

Principal components analysis. The first three PCA axes explain $73 \%$ of the variability in the species assemblage data (Table 4). The gradient represented by PCA axis 1 primarily reflects variations in the abundance of $P$. brevistriata, $S$. construens, and P. brevistriata v. elliptica. Some of the variation in S. elliptica is also captured in this axis. Also reflected in this axis is long-term change in the composition of sub-dominant taxa, which occur in abundances of 2$20 \%$ and can be visualized on the stratigraphic diagram as a shift to the right as one moves up the stratigraphic column. The second ordination axis, which explains nearly the same amount of variability as the first, most strongly reflects variation in S. pinnata ( $r=0.97)$, a dominant species for most of the Dzhangyskol record. The third ordination axis primarily reflects species diversity, with positive loadings on subdominant taxa and negative loadings of dominant taxa, particularly S. elliptica, and is positively correlated with both diversity indices $(r=0.63$ and $0.74, p<0.001$ ).

Table 4. Summary of principal components analysis (PCA) results.

\begin{tabular}{lcccc}
\hline & No. species & \multicolumn{3}{c}{ Eigenvalues (cumulative percentage of variance explained) } \\
\cline { 3 - 4 } & & Axis 1 & Axis 2 & Axis 3 \\
\hline Dzhangyskol & 49 & $0.293(29.3)$ & $0.285(57.8)$ & $0.153(73.1)$ \\
Grusha Ozero & 26 & $0.761(76.1)$ & $0.135(89.7)$ & $0.030(92.7)$ \\
Akkol & 14 & $0.540(54.0)$ & $0.239(77.8)$ & $0.139(91.7)$
\end{tabular}

Species or varieties occurring in relative abundances of at least $2 \%$ in one sample were included in the PCA, which was performed on the covariance matrix of relative abundance data. 


\section{Grusha Ozero}

\section{Chronology}

The chronology of the Grusha Ozero core is based on 16 radiocarbon dates (Table 1). In two instances, dates on macrofossils and bulk sediment collected from the same depth show overlapping calibrated age ranges. Median ages ranging from 10,930 to 11,480 cal year BP are reported from nine samples taken at seven depths between 130 and $185 \mathrm{~cm}$. Several of these dates are out of stratigraphic order but overlap in their ranges. The five dates between 130 and $155 \mathrm{~cm}$ appear too old, perhaps from the redeposition of shallow water sediments caused by climate-driven changes in lake-level. On that basis, we have excluded these dates from our age model. An age model $\left(r^{2}=0.99\right)$ was created by fitting a thirdorder polynomial to the remaining median calibrated age estimates (Figure 3b).

The oldest material from Grusha Ozero dates to 14,660 cal year BP. The model suggests a period of relatively rapid sediment accumulation between $\sim 12,000$ and 10,000 cal year BP (200-120 cm). The greatest uncertainty in this model lies in dating of the youngest sediments. The youngest sample $(55 \mathrm{~cm})$ dates to $6,900 \mathrm{cal}$ year $\mathrm{BP}$, which implies either a very slow sediment accumulation rate at the top of the sequence or an undetected hiatus in sedimentation.

\section{Loss-on-ignition}

$\mathrm{LOI}_{550}$ is less than $10 \%$ below $240 \mathrm{~cm}(\sim 14,600 \mathrm{cal}$ year BP) but exceeds 20\% above $234 \mathrm{~cm}(\sim 14,100$ cal year BP) (Figure $4 \mathrm{~b})$. LOI $_{550}$ maxima between 232 and $228 \mathrm{~cm}(\sim 14,000-13,700$ cal year BP), 190 and $150 \mathrm{~cm}(\sim 11,700-10,600 \mathrm{cal}$ year BP), and 90$50 \mathrm{~cm}(\sim 9,000-6,400$ cal year BP) correspond to fibrous sediment, the presence of fine and coarse detritus, and darker color. Maximum organic-matter content of $59 \%$ occurs at $50 \mathrm{~cm}(6,400 \mathrm{cal}$ year BP). Above $50 \mathrm{~cm}$, organic-matter content is stable at $\sim 30 \%$ until a recent ( last 800 cal year BP) increase. $\mathrm{LOI}_{950}$ is low throughout the core, never exceeding $3 \%$, indicating little or no carbonate.

\section{Diatoms (Figure 6)}

GR-1 (200-236 cm, 12,100-14,300 cal year BP). Diatoms first occur at $236 \mathrm{~cm}$. Diatoms are absent from
234 to $228 \mathrm{~cm}$ but reappear at $226 \mathrm{~cm}$. This zone is composed predominantly of the small benthic Fragilariaceae taxa S. elliptica and S. pinnata. Initially, this zone is characterized by a higher proportion of S. elliptica and low diversity. The latter half of the zone is distinguished by increased abundance of $S$. pinnata, S. construens, $P$. pseudoconstruens, and $P$. brevistriata and the first significant appearance of non-Fragilariaceae taxa.

GR-2 (155-195 cm, 10,700-11,900 cal year BP). Staurosirella elliptica is the most abundant taxon in this zone, which features step reductions in the abundance of $S$. pinnata and increased abundance of $P$. brevistriata. Species diversity is highest in this zone. A brief occurrence of $S$. pinnata v. intercedens (Grunow) Williams \& Round between 195 and 175 cm ( 11,900 and 11,200 cal year BP) and new occurrences of non-Fragilariaceae taxa above $175 \mathrm{~cm}$ also characterize zone GR-2. Important sub-dominant taxa in this zone include C. placentula v. lineata, Amphora pediculus (Kützing) Grunow, C. leptoceros, A. minutissimum (all varieties), Navicula vitabunda Hustedt, Navicula subrotundata Hustedt, and Cyclotella ocellata Pantocsek.

GR-3 (50-150 cm, 6,400-10,600 cal year BP). On average, this zone is characterized by the lowest diversity index values of the entire record. However, this is due largely to the extreme dominance of S. elliptica, particularly above $95 \mathrm{~cm}(\sim 9,200 \mathrm{cal}$ year BP). Staurosirella pinnata, which had previously been co-dominant, is found in low abundance. Pseudostaurosira brevistriata continues to be important, although its abundance decreases above $95 \mathrm{~cm}$. $\mathrm{Na}$ vicula diluviana appears as an important taxon numerically, with peak abundances below $95 \mathrm{~cm}$. Cyclotella ocellata also disappears above $95 \mathrm{~cm}$.

GR-4 (0-45 cm, 0-6,000 cal year BP). This zone features an abrupt increase in the abundance of $S$. pinnata, largely replacing $S$. elliptica as the dominant species. It is also characterized by the reappearance of $P$. pseudoconstruens and the first significant appearance of Synedra parasitica (W. Smith) Hustedt. Two samples, representing the past 800 years, show co-dominance of S. elliptica, S. pinnata, and S. construens. Diversity remains relatively low, with rare 


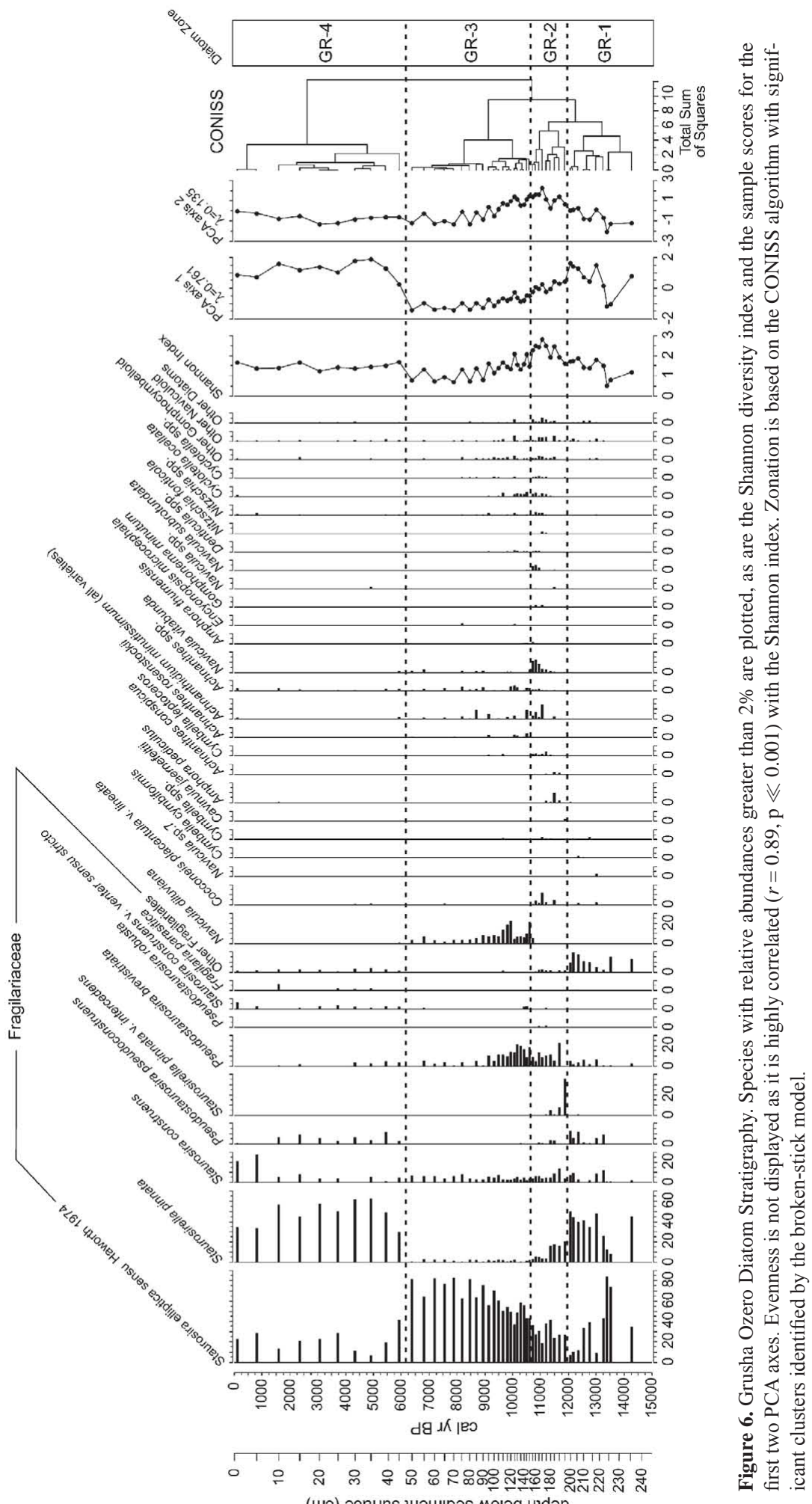


occurrences of C. ocellata, Achnanthes, Nitzschia, Naviculoid, and Gomphocymbelloid taxa.

Principal components analysis. The first two PCA axes explain $90 \%$ of the variability in the species assemblage data (Table 4). Most of this variation is captured in the first ordination axis, which reflects variation in the abundance of $S$. pinnata $(r=0.92, p \ll$ $0.001)$ and S. elliptica $(r=-0.94, \mathrm{p} \ll 0.001)$. Major shifts in axis 1 correspond to zone boundaries. PCA axis 2 primarily reflects variation in abundance of a number of sub-dominant taxa, including $P$. brevistriata and a number of non-Fragilariaceae taxa and is positively correlated to the Shannon index of species diversity ( $r=0.83$, $\mathrm{p} \ll 0.001)$.

\section{Akkol}

\section{Chronology}

The chronology of the Akkol core is based on 12 radiocarbon dates (Table 3). One date, at $428 \mathrm{~cm}$, is out of stratigraphic order. This sample provides the oldest date and has the largest uncertainty. Given the good fit of three other dates between 424 and $438 \mathrm{~cm}$, we have excluded this date from the age model. The chronology is composed of two separate age models to account for an abrupt change in sedimentation rate at approximately $425 \mathrm{~cm}(\sim 9,700 \mathrm{cal}$ year BP) (Figure $3 \mathrm{c}$ ). The first model, which applies from 0 to 424 $\mathrm{cm}$, is a third-order polynomial fit to nine dates with an $r^{2}$ of 0.99 . The second model, which applies from 425 to $438 \mathrm{~cm}$, is a linear fit of three dates with an $r^{2}$ of 0.99 . Below $438 \mathrm{~cm}$, the chronology is uncertain, constrained only by a minimum age of 13,400 cal year BP.

\section{Loss-on-ignition}

Organic matter ranges from 4 to 20\% by weight (Figure 4c). Except for a single high value of $13 \%$ at the base of the core, organic matter shows an increasing trend to its peak at $185 \mathrm{~cm}(\sim 5,900 \mathrm{cal}$ year BP). Subsequently, organic-matter content varies between 11 and $19 \%$ with no significant trend. $\mathrm{LOI}_{950}$, which may represent carbonates or dehydration of clay minerals, is low throughout the record, ranging from 1.3 to $3.7 \%$. No carbonates are present in the bedrock or glacial materials in the area.

\section{Biogenic silica}

BSi concentrations are low (less than $60 \mathrm{mg} \mathrm{g}^{-1}$ ) from the base of the core to $385 \mathrm{~cm}(\sim 8,800$ cal year $\mathrm{BP})$, then increase rapidly to $230 \mathrm{mg} \mathrm{g}^{-1}$ by $345 \mathrm{~cm}$ ( 8,000 cal year BP) (Figure 7). Above $345 \mathrm{~cm}, \mathrm{BSi}$ concentrations range between 110 and $220 \mathrm{mg} \mathrm{g}^{-1}$, before increasing abruptly again to a maximum concentration of $300 \mathrm{mg} \mathrm{g}^{-1}$ by $135 \mathrm{~cm}(\sim 5,000$ cal year $\mathrm{BP})$. Above $135 \mathrm{~cm}, \mathrm{BSi}$ concentrations show a decreasing trend that is punctuated by peaks at 75 and $45 \mathrm{~cm}(\sim 3,300$ and $2100 \mathrm{cal}$ year BP). BSi concentrations reach a late-Holocene minimum of $20 \mathrm{mg} \mathrm{g}^{-1}$ at $30 \mathrm{~cm}$ ( 1,500 cal year BP) but increase to $140 \mathrm{mg}$ $\mathrm{g}^{-1}$ by $10 \mathrm{~cm}$ ( $\sim 500 \mathrm{cal}$ year BP) and have changed little since then.

BSi is positively correlated ( $r=0.503, p=0.0002$ ) with organic-matter content, as estimated by $\mathrm{LOI}_{550}$, suggesting that sedimentary BSi may be a proxy for diatom productivity in Akkol. The application of sedimentary BSi as a proxy for paleoproductivity also assumes that silica was not limiting over the period of record and therefore is most appropriately applied in oligotrophic systems (Conley and Schelske 2001), a reasonable assumption in this case.

BSi accumulation rates range from a minimum of 0.04 to $5.0 \mathrm{mg} \mathrm{cm}^{-2}$ year-1 $^{-1}$. BSi accumulation is lowest in the silty sediment at the base of the core and in the top $35 \mathrm{~cm}$ (last 1,700 years). Maximum accumulation rates occur between 335 and $315 \mathrm{~cm}(\sim 7,900$ $7,600 \mathrm{cal}$ year BP) and subsequently show a gradual declining trend (Figure 7). Sub-millennial scale variations are also apparent against the background of declining BSi accumulation rates.

\section{Diatoms (Figure 8)}

The diatom record of Akkol is characterized by low diversity (i.e., few taxa in significant abundances) and minimal stratigraphic variation. By comparison, the complete Akkol record shows approximately the same magnitude of variability as a single zone within the Dzhangyskol and Grusha Ozero records.

AK-1 (145-455 cm, 5,200-15,000 cal year BP). This zone is co-dominated by S. elliptica and S. pinnata. Pseudostaurosira brevistriata and S. construens are sub-dominant. Diversity is low except for a single sample $(435 \mathrm{~cm})$ that corresponds to 

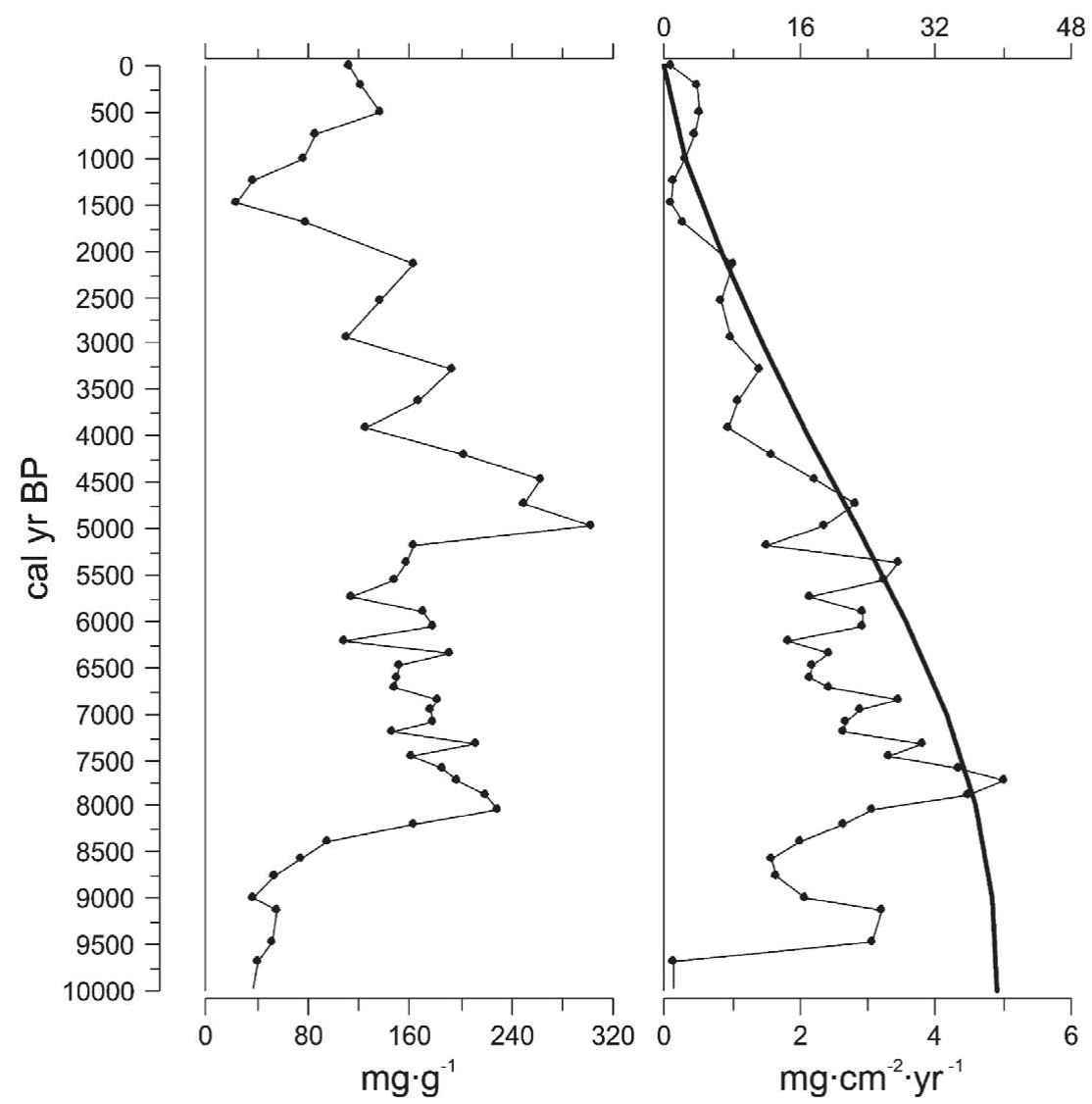

Figure 7. Akkol biogenic silica concentration and accumulation rates for the last 10,000 years. July insolation at $50^{\circ} \mathrm{N}$ (Berger and Loutre 1991) is plotted as deviations relative to present.

the period of low sedimentation during the late-glacial/early-Holocene. Another sample from this period $(445 \mathrm{~cm})$ was barren of diatoms. For a brief interval between 295 and $275 \mathrm{~cm}(\sim 7,000-7,300 \mathrm{cal}$ year BP), S. construens reaches maximum abundances of $33-40 \%$.

AK-2 (45-135 cm, 2,000-5,000 cal year BP). This zone is distinguished by increased abundance of $S$. pinnata and reduced abundance of $S$. elliptica and $P$. brevistriata.

AK-3 (0-35 cm, 0-1,700 cal year BP). Staurosirella pinnata persists as the dominant taxon in zone AK3. This zone is distinguished by further decline in the abundance of $S$. elliptica, reduced abundance of $S$. construens, and increasing abundances of $P$. brevistriata. Species diversity is at a maximum, especially from 0 to $20 \mathrm{~cm}$ ( last 1,000 years) as non-Fragilariaceae taxa occur with greater frequency. This is also the only period of the record when the Shannon and Evenness indices are significantly correlated $(r=$ $0.78, p=0.02$ ).

Principal components analysis. The first three axes explain $92 \%$ of the variation in the stratigraphic record (Table 4). More than half of the variation is represented by the first ordination axis, which, like the first ordination axis of the Grusha Ozero record, primarily reflects variation in the abundance of the two dominant taxa S. pinnata $(r=0.92, p \ll 0.001)$ and S. elliptica $(r=0.84, p \ll 0.001)$. The second ordination axis primary reflects variation in $S$. construens and to a lesser extent $P$. brevistriata, while the third axis is positively correlated ( $r=0.7, p \ll 0.001$ ) to the Shannon diversity index. 


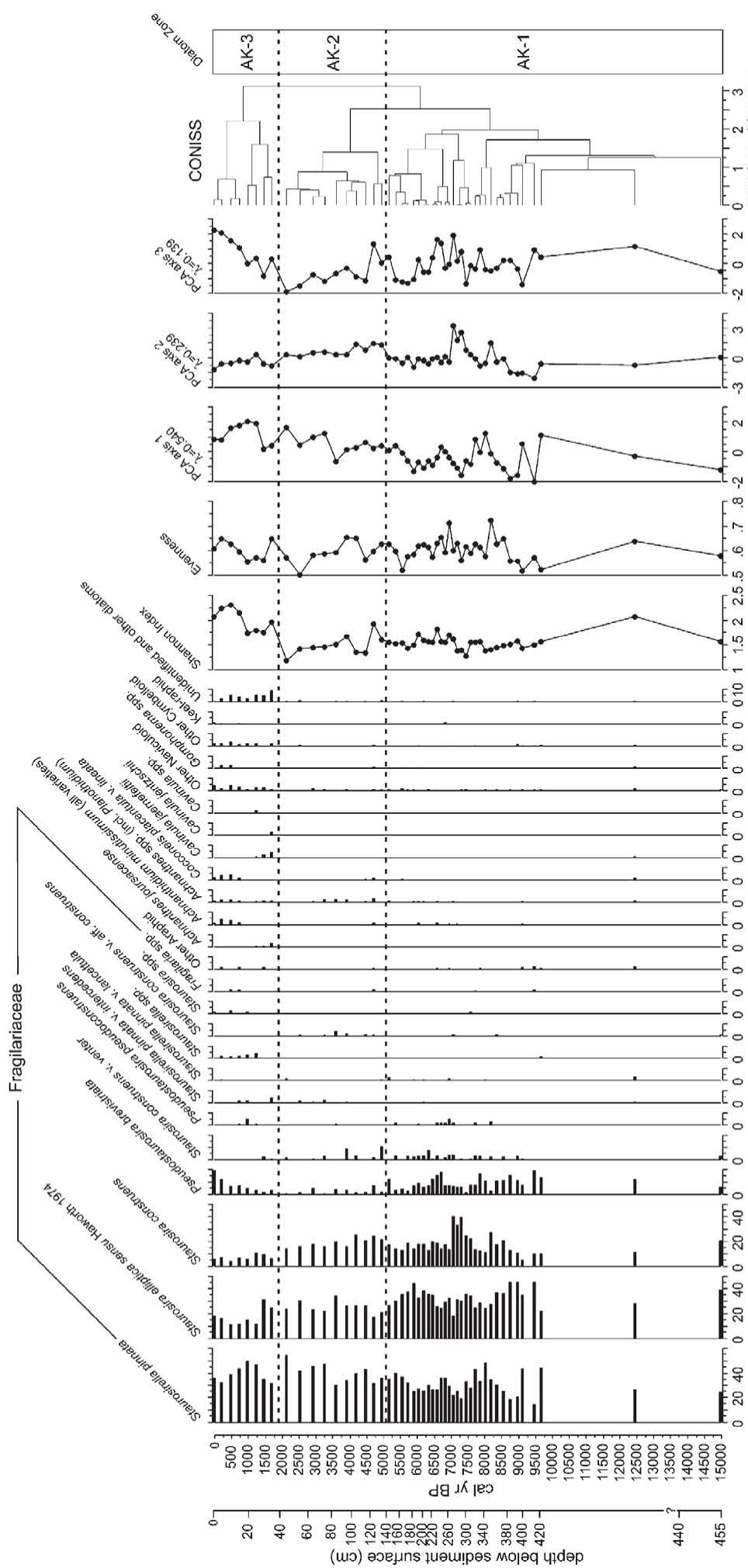




\section{Discussion}

The diatom records of Dzhangyskol, Grusha Ozero, and Akkol are broadly similar in terms of community structure and dominant taxa. Throughout their histories, all three lakes have lacked a significant planktonic community and have been dominated by small benthic alkaliphilic species of the Fragilariaceae family commonly found in alpine (Lotter et al. 1997; Karst-Riddoch et al. 2005) and arctic lakes (Douglas and Smol 1999; Laing and Smol 2000). The dominance of these taxa may be related to the high surface-to-volume ratio of small cells coupled with higher specific growth rates, which may confer a competitive advantage to small taxa under low nutrient conditions (Lotter et al. 1999). Furthermore, these taxa inhabit the littoral zone, which is the first area to become ice-free. Thus, these taxa may quickly form blooms and outcompete larger and/ or planktonic diatoms during the short growing season (Smol 1988; Lotter et al. 1999). However, these taxa also can dominate emergent coastal lakes (Stabell 1985), shallow, nutrient-rich lakes (Bennion et al. 2001), and late-glacial pioneer assemblages (Haworth 1976). Given the wide range of environments in which these taxa have been found, Anderson (2000) suggests that light and tolerance of physical disturbance may be the most important factors controlling their distribution.

The dominance of Staurosira, Staurosirella, and Pseudostaurosira species has made direct paleolimnological interpretations difficult, as our present understanding of diatom ecology lacks the detail necessary to interpret variation in species relative abundance among these taxa. At present, we lack a regional calibration set. A calibration dataset from the Alps is restricted to humid and sub-humid climates, making its extension to the more continental mountain ranges of Eurasia questionable. The mountains of southern Siberia feature high-elevation steppe landscapes, an environment in which the diatom distribution is unknown. Furthermore, these species' apparently wide ecological tolerances, especially with respect to nutrients, tend to reduce their predictive power (Bennion et al. 2001).

Although we lack information with which to draw climatic or environmental inferences directly from the diatom record, additional proxy data provide insight into the source of diatom assemblage variability. The diatom record of Grusha Ozero is characterized by large alternations in the relative abundance of S. pinnata and S. elliptica. The relative abundance of $S$. pinnata is significantly correlated $(r=0.84, p$ $\ll 0.001)$ with the first DCA axis of the chironomid record (Ilyashuk and Ilyashuk, unpublished data) of Grusha Ozero (Figure 9). This ordination axis of the chironomid record is interpreted as a temperature gradient and implies an association between high abundance of $S$. pinnata and cold temperatures. Conversely, S. elliptica corresponds to warmer temperatures. This association is consistent with the observations of Laing and Smol (2000) of the modern distribution of diatoms in lakes in three regions of Arctic Siberia. They found the highest abundances of S. pinnata in tundra lakes in all regions, while abundances in taiga lakes were usually less than $20 \%$. The distribution of $S$. construens v. venter, which is probably conspecific with the taxon we have identified as S. elliptica, is more complex. In the western and central regions, $S$. construens v. venter was abundant in all zones. However, in the eastern region, this taxon was found in highest abundance in the taiga zone, although at less than 20\% abundance.

At Grusha Ozero, the oldest pollen assemblage zone, which correlates with diatom zone GR-1, is dominated by herbaceous taxa (Artemisia, Poaceae, Cyperaceae, and Chenopodiaceae) similar to that of modern tundra-steppe plant communities described in the southeastern Altai (Blyakharchuk, unpublished data). After 11,900 cal year BP (195 cm), the pollen record indicates the decline of alpine meadow and development of a steppe-shrubland. This assemblage is absent from Akkol, which coupled with the radiocarbon results, suggests that the lake may have been dry at this time. The first appearance of the aquatic plant Myriophyllum verticillatum in Grusha Ozero also occurs during this period, corresponding to an interval of fibrous sediment. A more complex habitat associated with the presence of aquatic macrophytes could explain the high diversity of diatoms observed in GR-2. Arboreal pollen, particularly Pinus sibirica but also Picea obovata, Abies sibirica, and Larix sibirica, dominates between $\sim 10,400$ and $5,900 \mathrm{cal}$ year BP (140-45 cm). The beginning of this pollen 


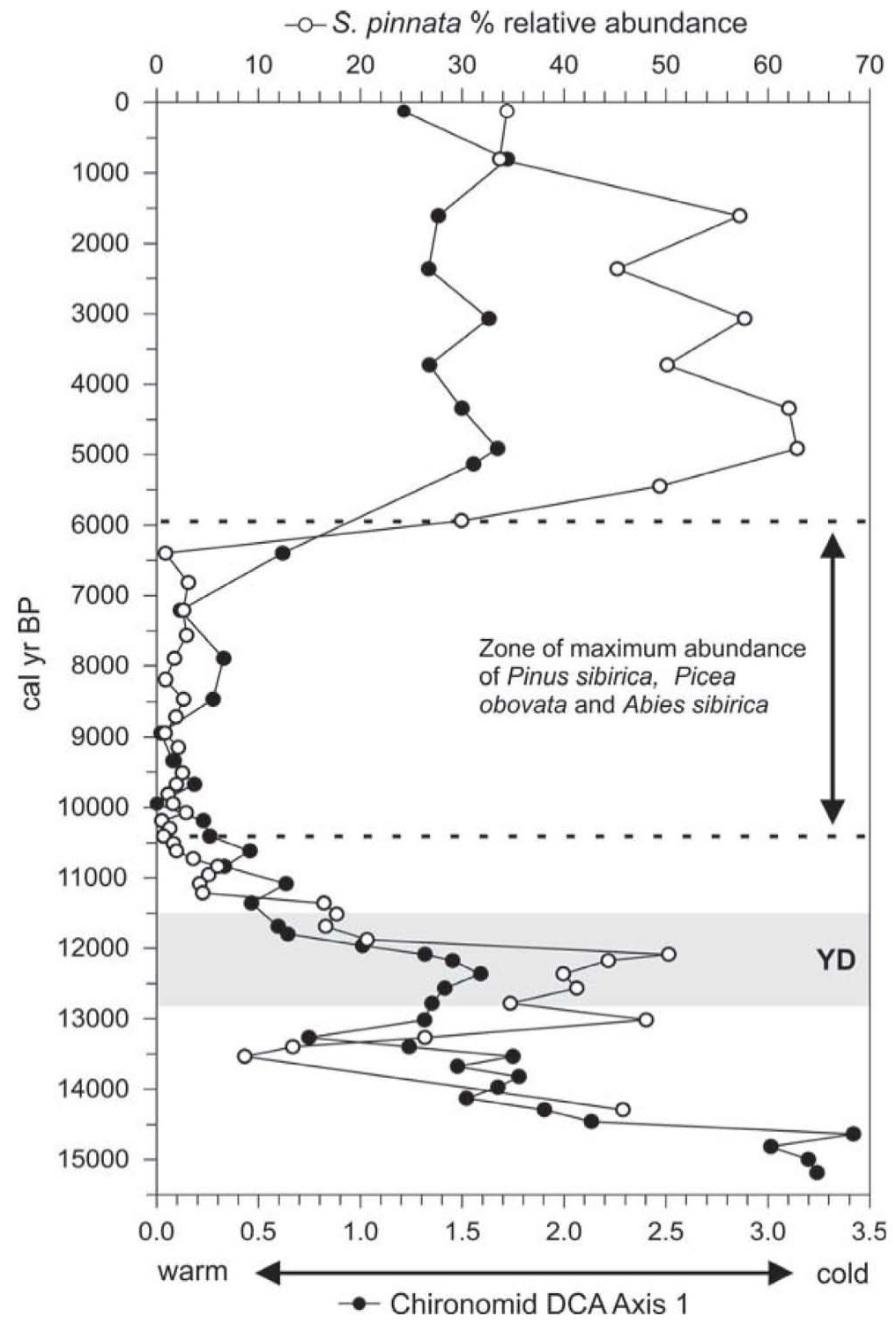

Figure 9. Correlation ( $r=0.84, p \ll 0.001$ ) between chironomid and diatom sedimentary records of Grusha Ozero. The first DCA axis of the chironomid record (Ilyashuk and Ilyashuk, unpublished data) is interpreted as a temperature gradient. The relative abundance of the diatom taxon $S$. pinnata decreases significantly during the inferred warm interval from $\sim 11,200$ to 6,000 cal year BP. The chironomid-inferred warm interval correlates with pollen evidence of increased Pinus sibirica, Picea obovata, and Abies sibirica, implying a warmer and more humid climate. A cooling oscillation between 13,300 and 11,900 cal year BP interrupted late-glacial warming. Given uncertainties in our chronology, this event may correspond to the Younger Dryas Stade denoted by the shaded box.

zone slightly lags the period of warm temperatures inferred from the chironomid record and the decline of $S$. pinnata (Figure 9). However, uncertainty in the age model during this interval precludes accurate estimation of the length of time represented by the lag. $\mathrm{LOI}_{550}$ nearly doubles to $40 \%$ between $\sim 12,100$ and 11,700 cal year BP (200 and $190 \mathrm{~cm}$ ), coinciding with the decline in S. pinnata and chironomid- inferred warming trend. Peak organic productivity, which occurs between 8,900 and 6,400 cal year BP (90 and $50 \mathrm{~cm}$ ) (Figure 4b), coincides with maximal abundance of Pinus sibirica. After $~ 5,900$ cal year BP $(45 \mathrm{~cm})$, an increase in S. pinnata and chironomid-inferred cooling correspond to decreased arboreal pollen ( $P$. sibirica, $P$. obovata, A. sibirica, and L. sibirica) and increased Artemisia and Poaceae. 
Despite their close proximity, the diatom records of Grusha Ozero and Akkol do not show a close correspondence. The low variability in the diatom record of Akkol implies a lack of sensitivity of the diatom community to climate and/or climate-mediated changes in the catchment and lake. Here, diatoms reveal a similar but much weaker relationship with chironomids than that observed at Grusha Ozero. The relative abundance of $S$. pinnata averaged 31\% between $\sim 9,700$ and 5,200 cal year BP (425-145 $\mathrm{cm}$ ) and increased to $40 \%$ after 5,200 cal year BP. Conversely, S. elliptica relative abundance averaged $33 \%$ prior to 5,200 cal year BP, but only $22 \%$ after that date. The chironomid record of Akkol suggests maximum warmth between $\sim 8,200$ and 6,200 cal year BP (355-205 cm) (Ilyashuk and Ilyashuk, unpublished data). The boundary between zones AK-1 and AK-2 at 5,200 cal year BP (145 cm) corresponds approximately to increases in herbaceous pollen at Akkol (Blyakharchuk, unpublished data). The differential response of otherwise similar diatom communities at Grusha and Akkol may be related to lake processes influenced by morphometry and landscape position.

Although diatom community composition shows little change, the record of BSi accumulation suggests that diatom productivity at Akkol has responded to millennial scale variability in climate driven by changes in insolation. Productivity in arctic and alpine lakes is particularly sensitive to climate as a consequence of short growing seasons. Warmer spring and summer temperatures induce earlier ice-off, with the result that a larger proportion of the lake is available for photosynthetic growth for a longer period of time (Smol 1988; Wolfe 2003). Furthermore, increased summer temperature may be linked to enhanced export of nutrients from catchment to lake (Wolfe 2003). Figure 7 compares BSi flux to changes in July insolation at $50 \mathrm{~N}$ over the past 10,000 years. From $\sim 7,900 \mathrm{cal}$ year BP $(335 \mathrm{~cm})$ to present, BSi accumulation rates show a gradual declining trend that corresponds to the decrease in insolation. The discrepancy between BSi accumulation rates and the insolation curve before 8,000 cal year BP may be related to high flux of minerogenic material, which is reflected in an LOI550 of less than $8 \%$ until $~ 8400$ cal year BP $(365 \mathrm{~cm})$. Aridity and related low water levels dur- ing the early-Holocene also may have reduced habitat availability and nutrient export. Sub-millennial variations in BSi accumulation rates superimposed on the long-term decreasing trend cannot be linked to higher-frequency variations in climate or solar forcing at this time.

Diatoms are largely absent from late-glacial sediments of Dzhangyskol, which at the time was a meltwater lake formed by advance of the Kurumundu glacier. Extended ice-cover (Smol 1988) and/or high rates of minerogenic sediment flux (Anderson 2000) may have inhibited development of a diatom community during this period. After $\sim 11,800$ cal year BP $(308 \mathrm{~cm})$, organic matter increased (Figure $4 \mathrm{a}$ ) as the surrounding landscape was vegetated and diatoms increased in abundance. Warm summers eventually led to failure of the ice dam and partial draining of the lake. An Artemisia steppe is inferred from the pollen record, and increases in pollen and spores of aquatic plants suggest warmer water. Increased diatom diversity and the abundance of non-Fragilariaceae epiphytic taxa in this zone are consistent with increasing habitat complexity in the aquatic environment and soil development in the catchment.

Increased moisture in the early-Holocene promoted a gradual transition from steppe to forest. The corresponding diatom assemblage is characterized by relatively low diversity with few non-Fragilariaceae taxa. Warm-water vegetation present in lacustrine sediment of the pingos suggests that Dzhangyskol did not freeze completely during winter (Butvilovsky 1993). An unconformity indicates draining of Dzhangyskol at the site of the core at 7,500 cal year BP, probably caused by diversion of its inflowing meltwater stream. The lake refilled and deposition resumed by $\sim 5,500$ cal year BP. A shift in $\delta^{18} \mathrm{O}$ of bio-induced carbonate from -17 to $-9 \%$ (Wright and Ito, unpublished data) coinciding with the unconformity, implies a shift from a primary glacial meltwater source to a local precipitation source. The diatom community shows no response to this change in water source or size of the lake.

After 6,500 cal year BP forests of Pinus sibirica and Larix siberica expanded to replace more mesophilous Abies and Picea species, while steppe communities spread in the dry intermontane basins and south-facing slopes. Staurosirella pinnata, the taxon 
associated with cooler temperatures in the Grusha Ozero record, increased in abundance after $\sim 5,000$ cal year BP $(112 \mathrm{~cm})$. The development of pingos and expansion of permafrost after $\sim 2,100$ cal year BP coincide approximately with the onset of DZH-2.

Grusha Ozero provides the oldest and most complete record of late-glacial climatic and ecological change. The chironomid and diatom records (Figure 9) suggest initial warming of climate after $\sim 14,300$ cal year BP, interrupted by a return to cooler temperatures between $\sim 13,300$ and 11,900 cal year BP (222 and $195 \mathrm{~cm}$ ). This period is also characterized by a decrease in organic matter (Figure 4b). The increase in organic matter at the end of this interval, which signals increased terrestrial and aquatic productivity, is a common feature of the Younger Dryas/Holocene boundary. This climatic oscillation is not evident in the pollen record. Although our chronology indicates this event slightly predates the Younger Dryas Stade ( 12,800-11,500 cal year BP; Alley 2000), uncertainty in our age model is large enough that this event may be contemporaneous with the Younger Dryas Stade. After $\sim 12,000$ cal year BP, continued aridity is inferred from the dominance of Artemisia steppe and the possible drying of Akkol.

By 10,400 cal year BP $(140 \mathrm{~cm})$ chironomids, diatoms, and pollen suggest climatic warming that is consistent with upslope movement of altitudinal vegetation belts reported from a site north of the Karaginskaya Basin (Ponomareva et al. 1991; Butvilovsky 1993) and development of closed forests with Picea and Abies in the central Altai (Blyakharchuk et al. 2004). The expansion of forest into the interior ranges, where moisture is presently limiting, also indicates increased humidity. The period between $\sim 8,200$ and 6,500 cal year BP is inferred to be the warmest and most humid, based on the maximum occurrence of A. sibirica (the most thermophilous tree among Siberian species) and is consistent with maximum diatom productivity at Akkol. However, there is no response in diatom community composition to these inferred changes in effective moisture.

Deforestation after $\sim 6,000$ cal year BP is consistent with chironomid and diatom evidence of cooling. In the Karaginskaya basin, the disappearance of dark-coniferous forests and expansion of steppe and herbaceous alpine taxa suggest colder and drier con- ditions. These changes coincide with the expansion of the more continental Pinus and Larix and decline of Picea and Abies in the western Altai (Blyakharchuk et al. 2004).

The response of the diatom communities in these lakes to warming and forest expansion differs from changes reported in other Eurasian paleolimnological studies (Laing et al. 1999; Lotter and Bigler 2000) and modern calibration studies (Lotter et al. 1997; Laing and Smol 2000) that span arctic and alpine treeline. One reported response to increased temperatures has been an increase in planktonic taxa, associated with longer growing seasons, altered thermal regimes, changes in transparency, and/or nutrient availability. The shallow depths of our study lakes may have precluded these lakes from exhibiting such a response. With respect to changes in benthic taxa associated with changes in alkalinity, DOC, and/ or nutrients caused by vegetation change, it is possible, in the cases of Grusha Ozero and Akkol, that their catchments were never forested. The elevated percentage of arboreal pollen could simply reflect the advance of the forest limit, which is currently 40 $\mathrm{km}$ to the west of the study sites, sufficiently close to contribute pollen to the watersheds. The lack of a diatom response to the shift from steppe to forested catchment at Dzhangyskol during the early-Holocene may reflect the contribution of glacial meltwater via the Kurkurek River. However, the lack of a response of the diatoms following the isotope-inferred diversion of this river seems inconsistent with this explanation. Perhaps frequent disturbance and cooling temperatures favored Fragilariaceae taxa after resumption of sedimentation.

Although the diatom floras of the three study lakes are quite similar, clear differences exist in the magnitude of stratigraphic variation of the diatom assemblages, and by inference the sensitivity of the lakes to environmental variability. Grusha Ozero and Dzhangyskol feature the most variability, although it is manifested among different parts of the diatom community. Grusha Ozero experienced abrupt fluctuations in the abundance of its dominant Fragilariaceae taxa, while more of Dzhangyskol's variation was related to changes in the abundance of its sub-dominant and rare taxa. The apparent long-term turnover of the subdominant and rare taxa may reflect long-term soil and vegetation development in 
the catchment, which could be expected to influence nutrient and DOC exports to the lake. In addition, Dzhangyskol, which is situated at a lower elevation and within a more humid zone, is characterized by a numerically richer flora than the steppe lakes. Both Dzhangyskol and Akkol show increasing trends in diatom diversity beginning at $\sim 2,000$ cal year BP and peaking in the past 750 years.

\section{Conclusions}

From the late-glacial to the present, the diatom floras of Dzhangyskol, Grusha Ozero, and Akkol have been dominated by small Fragilariaceae taxa. These ecological generalists are common in lakes at high elevations and high latitudes, where ice-free intervals are short and nutrient supply is low, although they occur across a wide ecological gradient. Dzhangyskol, the only lake presently located in a forested catchment, has the richest flora and has experienced long-term turnover of its subdominant and rare taxa.

Direct paleoenvironmental interpretations from the diatom record are limited by the apparent complexity of environmental drivers and a lack of information on the ecological affinities of the dominant taxa. The diatom record of Grusha Ozero, located within the high-elevation Karaginskaya basin, is characterized by abrupt shifts in dominance between S. elliptica and S. pinnata, in addition to more subtle changes in the composition of its subdominant taxa. Based on chironomid analysis of the same core, variability in the relative abundance of $S$. pinnata appears to reflect millennial-scale fluctuations in temperature. Akkol, also located in the Karaginskaya basin, has shown significantly less variability in the composition of its diatom community through time, although the last 2,000 years have featured increased diversity. However, diatom productivity, inferred from accumulation rates of biogenic silica, appears to track declining insolation over the past 8,000 years. A more refined understanding of the proximate control on diatom distribution, particularly in freshwater lakes of the interior steppe, is required to fully explain the major components of stratigraphic variation of the diatom record in the Altai lakes investigated.

Late-glacial and Holocene millennial-scale climatic variability is inferred from synthesis of all available proxies (diatoms, chironomids, pollen, $\mathrm{BSi}$, and LOI). Cooling that is probably correlative to the Younger Dryas Stade is detected. The early-Holocene was characterized by a warmer and more humid climate that resulted in afforestation of steppe landscapes. Temperature and humidity began to wane by $\sim 6,000$ cal year BP, and the modern biomes became established.

\section{Acknowledgments}

This research was supported by grants to H. E. Wright and S. C. Fritz from the National Science Foundation and the National Geographic Society. Pavel Blyakharchuk, Pavel Borodavko, and Brigitta Ammann assisted with collection of the sediment cores analyzed in this study. Boris Ilyashuk and Elena Ilyashuk generously shared the results of their chironomid analysis of Grusha Ozero and Akkol. Florencia Oberli analyzed the sediments for LOI at the University of Bern.

\section{References}

Alley R.B. 2000. The Younger Dryas cold interval as viewed from central Greenland. Quat. Sci. Rev. 19: 213-226.

Anderson N.J. 2000. Diatoms, temperature and climatic change. Eur. J. Phycol. 35: 307-314.

Andreev A.A., Siegert C., Klimanov V.A., Derevyagin A.Y., Shilova G.N., and Melles M. 2002. Late Pleistocene and Holocene vegetation and climate on the Taymyr Lowland, Northern Siberia. Quat. Res. 57: 138-150.

Beniston M., Diaz H.F. and Bradley R.S. 1997. Climatic change at high elevation sites: an overview. Climatic Change 36: 233-251.

Bennett K.D. 1996. Determination of the number of zones in a biostratigraphical sequence. New Phytol. 132: 155-170.

Bennett K.D. 2002. Documentation for psimpoll 4.10 and pscomb 1.03. http://www.kv.geo.uu.se/psimpoll.html

Bennion H., Appleby P.G., and Phillips G.L. 2001. Reconstructing nutrient histories in the Norfolk Broads, UK: implications for the role of diatom-total phosphorus transfer functions in shallow lake management. J. Paleolimnol. 26: 181-204.

Berger A. and Loutre M.F. 1991. Insolation values for the climate of the last 10 million years. Quat. Sci. Rev. 10: 297-317.

Blyakharchuk T.A. 2003. Four new pollen sections tracing the Holocene vegetational development of the southern part of the West Siberian Lowland. The Holocene 13: 715-731.

Blyakharchuk T.A. and Sulerzhitskiy L.D. 1999. Holocene vegetational and climatic changes in the forest zone 
of Western Siberia according to pollen records from the extrazonal palsa bog Bugristoye. The Holocene 9: 621-628.

Blyakharchuk T.A., Wright H.E., Borodavko P.S., van der Knaap W.O., and Ammann B. 2004. Late-glacial and Holocene vegetational changes on the Ulagan high-mountain plateau, Altai Mountains, southern Siberia. Paleogeogr. Paleoclimatol. Paleoecol. 209: 259-279.

Borisov A.A. 1965. Climates of the U.S.S.R. Aldine Pub. Co, Chicago, 255 pp.

Butvilovsky V.V. 1993. Paleogeografiya poslednego oledeneniya i Golotsena Altaya: sobytiino-katastroficheskaya model' (Palaeogeography of the last glaciation and Holocene of Altai: event-catastrophic model). Tomsk State University Press, Tomsk, 252 pp. (in Russian)

Camburn K.E. and Charles D.F. 2000. Diatoms of Low-alkalinity Lakes in the Northeastern United States. The Academy of Natural Sciences of Philadelphia, Philadelphia, 152 pp.

Conley D.J. 1998. An interlaboratory comparison for the measurement of biogenic silica in sediments. Mar. Chem. 63: 39-48.

Conley D.J. and Schelske C.L. 2001. Biogenic silica. In: Smol J.P., Birks H.J.B., and Last W.M. (eds), Tracking Environmental Change Using Lake Sediments Volume 3: Terrestrial, Algal, and Siliceous Indicators. Kluwer, Dordrecht, pp. 281-293.

Davydova N.N., Subetto D.A., Khomutova V.I., and Sapelko T.V. 2001. Late Pleistocene-Holocene paleolimnology of three northwestern Russian lakes. J. Paleolimnol. 26: 37-51.

DeMaster D.J. 1979. The marine budgets of silica and ${ }^{32} \mathrm{Si}$. Ph.D. Dissertation, Yale University, 308 pp.

Douglas M.S.V. and Smol J.P. 1999. Freshwater diatoms as indicators of environmental change in the High Arctic. In: Stoermer E.F. and Smol J.P. (eds), The Diatoms: Applications for the Environmental and Earth Sciences. Cambridge University Press, Cambridge, pp. 227-244.

Fallu M.-A., Allaire N., and Pienitz R. 2000. Freshwater diatoms from northern Québec and Labrador (Canada). Bibliotheca Diatomologica Band 45. J. Cramer, Berlin, 200 pp.

Fowell S.J., Hansen B.C.S., Peck J.A., Khosbayar P., and Ganbold E. 2003. Mid to late Holocene climate evolution of the Lake Telmen Basin, North Central Mongolia, based on palynological data. Quat. Res. 59: 353-363.

Glebov F.Z., Karpenko L.V., and Dahkovskaya I.S. 2002. Climatic changes, successions of peatlands and zonal vegetation, and peat accumulation dynamics in the Holocene (the West-Siberia peat profile "Vodorasdel." Climatic Change 55: 175-181.

Groisman P. 1998. Former Soviet Union Monthly Precipitation Archive, 1891-1993. Data provided by the EOS Distributed Active Archive Center (DAAC) at the National Snow and Ice Data Center. University of Colorado, Boulder, CO.

Harrison S.P., Prentice I.C., and Bartlein P.J. 1992. Influence of insolation and glaciation on atmospheric circulation in the North Atlantic sector: implications of General Circulation Model experiments for the late Quaternary of Europe. Quat. Sci. Rev. 11: 283-299.

Harrison S.P., Yu G., and Tarasov P.E. 1996. Late Quaternary lake-level record from northern Eurasia. Quat. Res. 45: 138-159.

Haworth E.Y. 1974. A scanning electron microscope study of some different frustule forms of the genus Fragilaria found in Scottish late-glacial sediments. Br. Phycol. J. 10: 73-80.

Haworth E.Y. 1976. Two late-glacial (Late Devensian) diatom assemblage profiles from northern Scotland. New Phytol. 77: 227-256.

Heiri O., Lotter A.F., and Lemcke G. 2001. Loss-on-ignition as a method for estimating organic and carbonate content in sediments: reproducibility and comparability of results. J. Paleolimnol. 25: 101-110.

Karst-Riddoch T.L., Pisaric M.F.J., and Smol J.P. 2005. Diatom responses to 20th century climate-related environmental changes in high-elevation mountain lakes of the northern Canadian Cordillera. J. Paleolimnol. 33: 265-282.

Khotinskiy N.A. 1984. Holocene vegetation history. In: Velichko A.A., Wright H.E. Jr., and Barnosky C.W. (eds), Late Quaternary Environments of the Soviet Union. University of Minnesota Press, Minneapolis, pp. 179-200.

Koropachinsky I.Y. 1996. Green Book of Siberia: Rare and Endangered Plant Communities. Nauka (Russian Academy of Sciences, Novosibirsk, 396 pp (in Russian).

Krammer K. and Lange-Bertalot H. 1986-1991. Bacillariophyceae. In: Ettl H., Gerloff J., Heynig H., and Mollenhauser D. (eds), Süßwasserflora von Mitteleuropa Band 2(1-4). Gustav Fisher Verlag, Stuttgrat/Jena.

Kremenetski K.V., Velichko A.A., Borisova O.K., MacDonald G.M., Smith L.C., Frey K.E., and Orlova L.A. 2003. Peat-lands of the Western Siberian lowlands: current knowledge on zonation, carbon content and Late Quaternary history. Quat. Sci. Rev. 22: 703-723.

Kultti S., Väliranta M., Sarmaja-Korjonen K., Solovieva N., Virtanen T., Kauppila T., and Eronen M. 2003. Palaecological evidence of changes in vegetation and climate during the Holocene in the pre-Polar Urals, northeast European Russia. J. Quat. Sci. 18: 503-520.

Laing T.E., Rühland K.M., and Smol J.P. 1999. Past environmental and climatic changes related to tree-line shifts inferred from fossil diatoms from a lake near the Lena River Delta, Siberia. Holocene 9: 547-557.

Laing T.E. and Smol J.P. 2000. Factors influencing diatom distributions in circumpolar treeline lakes of northern Russia. J. Phycol. 36: 1035-1048.

Lange-Bertalot H. and Metzelin D. 1996. Indicators of Oligotrophy. Iconogr. Diatomol. Vol. 2, 390 pp.

Lepš J. and Šmilauer P. 2003. Multivariate Analysis of Ecological Data using CANOCO. Cambridge University Press, Cambridge, UK, 269 pp.

Lotter A.F. and Bigler C. 2000. Do diatoms in the Swiss Alps reflect the length of ice-cover? Aquat. Sci. 62: 125-141. 
Lotter A.F., Birks H.J.B., Hofmann W., and Marchetto A. 1997. Modern diatom, cladocera, chironomid, and chrysophyte cyst assemblages as quantitative indicators for the reconstruction of past environmental conditions in the Alps. I. Climate. J. Paleolimnol. 18: 395-420.

Lotter A.F., Pienitz R., and Schmidt R. 1999. Diatoms as indicators of environmental change near arctic and alpine treeline. In: Stoermer E.F. and Smol J.P. (eds), The Diatoms: Applications for the Environmental and Earth Sciences. Cambridge University Press, Cambridge, pp. 205-226.

Lydolph P.E. 1977. Climates of the Soviet Union (World Survey of Climatology 7). Elsevier Scientific Publishing, Amsterdam, $441 \mathrm{pp}$.

MacDonald G.M., Velichko A.A., Kremenetski C.V., Borisova O.K., Goleva A.A., Andreev A.A., Cwynar L.C., Riding R.T., Forman S.L., Edwards T.W.D., Aravena R., Hammarlund D., Szeicz J.M., and Gattaulin V.N. 2000. Holocene treeline history and climate change across northern Eurasia. Quat. Res. 53: 302-311.

Malyshev L. and Nimis P.L. 1997. Climatic dependence of the ecotone between alpine and forest orobiomes in southern Siberia. Flora 192: 109-120.

Overpeck J.T., Webb T. III, and Prentice I.C. 1985. Quantitative interpretation of fossil pollen spectra: dissimilarity coefficients and the method of modern analogs. Quat. Res. 23: 87-108.

Peck J.A., Khosbayar P., Fowell S.J., Pearce R.B., Ariunbileg S., Hansen B.C.S., and Soninkhishig N. 2002. Mid to Late Holocene climate change in north central Mongolia as recorded in the sediments of Lake Telmen. Paleogeogr. Paleoclimatol. Paleoecol. 183: 135-153.

Peteet D., Andreev A., Bardeen W., and Mistretta F. 1998. Long-term Artic peatland dynamics, vegetation, and climate history of the Pur-Taz region, Western Siberia. Boreas 27: 115-126.

Pisaric M.F.J., MacDonald G.M., Velichko A.A., and Cwynar L.C. 2001. The Lateglacial and Postglacial vegetation history of the northwestern limits of Beringia, based on pollen, stomate and tree stump evidence. Quat. Sci. Rev. 20: 235-245.

Ponomareva E.A., Butvilovsky V.B., and Orlova L.A. 1991. Section Bogoyash-basic Holocene section of the high mountain belt of southeastern Altai. In: Baryshnikov G. Ya. (ed.), Novye dannye po geologicheskomy stroeniyu i usloviyam formirovaniya mestorozhdenii poleznukh iskopaemykh v Altaiskom krae. Altai State University, Barnaul.

Porinchu D.F. and Cwynar L.C. 2002. Late-Quaternary history of midge communities and climate from a tundra site near the lower Lena River, Northeast Siberia. J. Paleolimnol. 27: 59-69.
Smol J.P. 1988. Paleoclimate proxy data from freshwater arctic diatoms. Verh. Int. Ver. Limnol. 23: 837-844.

Stabell B. 1985. The development and succession of taxa within the diatom genus Fragilaria Lyngbye as a response to basin isolation from the sea. Boreas 14: 273-286.

Stuiver M. and Reimer P.J. 1993. Extended ${ }^{14} \mathrm{C}$ database and revised CALIB radiocarbon calibration program. Radiocarbon 35: 215-230.

Stuiver M., Reimer P.J., and Braziunas T.F. 1998a. High-precision radiocarbon age calibration for terrestrial and marine samples. Radiocarbon 40: 1127-1151.

Stuiver M., Reimer P.J., Bard E., Beck J.W., Burr G.S., Hughen K.A., Kromer B., McCormac F.G., v. d. Plicht J., and Spurk M. 1998b. INTCAL98 Radiocarbon age calibration 24,000-0 cal BP. Radiocarbon 40: 1041-1083.

Tarasov P., Dorofeyuk N., and Metel’tseva E.V. 2000. Holocene vegetation and climate changes in Hoton-Nur basin, northwest Mongolia. Boreas 29: 117-126.

Tarasov P.E., Guiot J., Cheddadi R., Andreev A.A., Bezusko L.G., Blyakharchuk T.A., Dorofeyuk N.I., Filimonova L.V., Volkova V.S., and Zernitskaya V.P. 1999. Climate in northern Eurasia 6000 years ago reconstructed from pollen data. Earth Planet. Sci. Lett. 171: 635-645.

ter Braak C.J.F. and Šmilauer P. 1998. CANOCO reference manual and user's guide to Canoco for Windows: software for canonical community ordination (version 4). Microcomputer Power, Ithaca, New York, 352 pp.

Väliranta M., Kaakinen A., and Kuhry P. 2003. Holocene climate and landscape evolution east of the Pechora Delta, East-European Russian Arctic. Quat. Res. 59: 335-344.

Williams D.M. and Round F.E. 1987. Revision of the genus Fragilaria. Diatom Res. 2: 267-288.

Wolfe B.B., Edwards T.W.D., Aravena R., Forman S.L., Warner B.G., Velichko A.A., and MacDonald G.M. 2000. Holocene paleohydrology and paleoclimate at treeline, north-central Russia, inferred from oxygen isotope records in lake sediment cellulose. Quat. Res. 53: 319-329.

Wolfe A.P. 2003. Diatom community responses to late-Holocene climatic variability, Baffin Island, Canada: a comparison of numerical approaches. Holocene 13: 29-37.

WWF Climate Program. 2001. Climate Passport of the AltaiSayan Ecoregion. World Wildlife Foundation, Moscow, $26 \mathrm{pp}$.

Wright H.E. Jr. 1991. Coring tips. J. Paleolimnol. 6: 37-49.

Yu G. and Harrison S.P. 1995. Holocene changes in atmospheric circulation patterns as shown by lake status changes in northern Europe. Boreas 24: 260-268. 